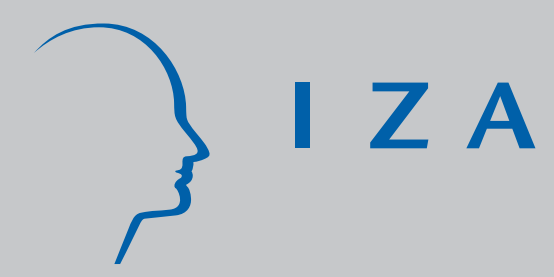

IZA DP No. 4050

Can a Task-Based Approach Explain the Recent Changes in the German Wage Structure?

DirkAntonczyk

Bernd Fitzenberger

Ute Leuschner

February 2009 


\title{
Can a Task-Based Approach Explain the Recent Changes in the German Wage Structure?
}

\author{
Dirk Antonczyk \\ Albert-Ludwigs-University Freiburg \\ Bernd Fitzenberger \\ Albert-Ludwigs-University Freiburg \\ IFS, ZEW and IZA \\ Ute Leuschner \\ Albert-Ludwigs-University Freiburg
}

Discussion Paper No. 4050

February 2009

IZA
P.O. Box 7240
53072 Bonn
Germany

Phone: +49-228-3894-0

Fax: +49-228-3894-180

E-mail: iza@iza.org

\begin{abstract}
Any opinions expressed here are those of the author(s) and not those of IZA. Research published in this series may include views on policy, but the institute itself takes no institutional policy positions.

The Institute for the Study of Labor (IZA) in Bonn is a local and virtual international research center and a place of communication between science, politics and business. IZA is an independent nonprofit organization supported by Deutsche Post Foundation. The center is associated with the University of Bonn and offers a stimulating research environment through its international network, workshops and conferences, data service, project support, research visits and doctoral program. IZA engages in (i) original and internationally competitive research in all fields of labor economics, (ii) development of policy concepts, and (iii) dissemination of research results and concepts to the interested public.
\end{abstract}

IZA Discussion Papers often represent preliminary work and are circulated to encourage discussion. Citation of such a paper should account for its provisional character. A revised version may be available directly from the author. 


\section{ABSTRACT}

\section{Can a Task-Based Approach Explain the Recent Changes in the German Wage Structure?*}

This paper investigates the changes in the German wage structure for full-time working males from 1999 to 2006. Our analysis builds on the task-based approach introduced by Autor et al. (2003), as implemented by Spitz-Oener (2006) for Germany, and also accounts for job complexity. We perform a Blinder-Oaxaca type decomposition of the changes in the entire wage distribution between 1999 and 2006 into the separate effects of personal characteristics and task assignments. In line with the literature, we find a noticeable increase of wage inequality between 1999 and 2006. The decomposition results show that the changes in personal characteristics explain some of the increase in wage inequality whereas the changes in task assignments strongly work towards reducing wage inequality. The coefficient effect for personal characteristics works towards an increase in wage inequality at the top of the wage distribution. The coefficient effect for the task assignments on the contrary shows an inverted U-shaped pattern. We conclude that altogether the task-based approach can not explain the recent increase of wage inequality in Germany.

JEL Classification: J24, J31, D31, C43

Keywords: wage inequality, occupations, tasks, skill biased technical change, polarization

Corresponding author:

Bernd Fitzenberger

Department of Economics

Albert-Ludwigs-University

79085 Freiburg

Germany

E-mail: bernd.fitzenberger@vwl.uni-freiburg.de

\footnotetext{
* Bernd Fitzenberger dedicates this paper to his academic advisor and friend Wolfgang Franz at the occasion of his 65th birthday in January 2009. The work in this paper benefitted from discussions with David Autor, Christian Dustmann, Stephen Machin, and Alexandra Spitz-Oener. We are grateful for the comments by three anonymous referees. This paper was written as part of the research project "Collective Bargaining and the Distribution of Wages: Theory and Empirical Evidence" within the DFG research network "Flexibility in Heterogeneous Labor Markets" (FSP 1169). Financial support from the German Science Foundation (DFG) is gratefully acknowledged. We thank the German Federal Institute for Vocational Training (BIBB) for letting us use the data for 2006. The responsibility for all errors is, of course, ours.
} 


\section{Contents}

1 Introduction 1

2 Data 6

3 Econometric Approach $\quad 10$

3.1 Estimated Model . . . . . . . . . . . . . . . . . . . . 11

3.2 Simulation and Decomposition . . . . . . . . . . . . . . . . . 12

4 Results $\quad 15$

4.1 Descriptive Evidence . . . . . . . . . . . . . . . . . 16

4.2 Parameter Estimates . . . . . . . . . . . . . . . . . . . . . . 17

4.3 Decomposition Results . . . . . . . . . . . . . . . . . . . . . . . 19

5 Conclusions 20

$\begin{array}{lr}\text { Appendix } & 24\end{array}$ 


\section{Introduction}

Wage inequality has been rising in Germany after all (Fitzenberger, 1999; Dustmann et al., 2007; Kohn, 2006; Gernandt and Pfeiffer, 2007). ${ }^{1}$ In comparison to the strong increase in wage inequality in the US and the UK since the early 1980s (Katz and Autor, 1999; Goos and Manning, 2007), the increase of wage inequality in Germany has been delayed and less pronounced. The increase of wage inequality in Germany was restricted to the top of the wage distribution in the 1980s and at the bottom of the wage distribution, it only started to grow in the mid 1990s. This is in contrast to the US, where wage inequality in the 1990s continued to grow at the top of the wage distribution, whereas wage inequality at the bottom did not grow further (Autor et al., 2008). Our paper investigates recent changes in wage inequality in Germany for the time period 1999 to 2006 in light of the tasked based approach of Autor et al. (2003).

The most prominent explanation in the literature for the wage changes in the US and the UK is skill-biased technical change (SBTC) resulting in an increasing demand for more highly skilled labor (see the survey by Katz and Autor, 1999). The increase in demand is stronger than the parallel increases in the supply of more highly skilled labor. Furthermore, Acemoglu (1998) argues that the rise in the supply of high-skilled workers in the 1970s and 1980s through the expansion of the education system resulted in the development of skill-complementary technologies causing SBTC. The simple SBTC hypothesis predicts rising wage inequality over the entire wage distribution, which is not consistent with the fact that inequality at the bottom of the wage distribution in the US stopped to grow further during the 1990s despite a continuous improvement of computer technology (Acemoglu, 1998; Goos and Manning, 2007). The developments in Germany for the 1980s are consistent with the SBTC hypothesis (Fitzenberger, 1999), if one allows for the possibility that growing wage inequality at the bottom of the wage distribution is prevented by labor market institutions such as unions and implicit minimum wages implied by the welfare state. In a similar vein for the US, DiNardo et al. (1996) argue that increasing wage inequality in the 1980s and the early 1990s may partly be explained by changing labor market institutions, i.e. falling real minimum wages and deunionization. Based on administrative data from the IAB, Dustmann et al. (2007) show that wage inequality in West Germany has been rising since the 1980s. ${ }^{2}$ The study argues that wage inequality at the top of the wage distribution began to rise during the 1980s (see also Fitzenberger, 1999 and Fitzenberger and Kohn, 2006) whereas wage inequality at the

\footnotetext{
${ }^{1}$ The first sentence is a variation of the title of the paper by Kohn (2006).

${ }^{2}$ See also Kohn (2006), and Gernandt and Pfeiffer (2007) who document rising wage inequality in West Germany since the mid 1990s based on the IAB data and the German Socioeconomic Panel, respectively.
} 
bottom of the wage distribution only started to increase during the 1990s. The strong deunionization (Fitzenberger et al., 2006) is likely to have contributed to the increase in inequality at the bottom of the wage distribution. Gernandt and Pfeiffer (2007) find that the increase in wage inequality between 1994 and 2005 has been much stronger for workers with low tenure compared to workers with high tenure. Thus, changes in wages over time seem to take place predominantly for new hirings whereas workers with higher tenure seem much less affected.

Autor et al. (2003) propose a nuanced version of the SBTC hypothesis by operationalizing the way technology affects the labor market through the tasks performed at a job. Occupations are distinguished by the composition of the different tasks. This task-based approach argues that technological change results in a substitution of routine tasks by computers and other machines. Therefore, demand for workers performing non-routine tasks increases. For the US, Autor et al. (2003) analyze data at the occupational level and confirm that the employment in jobs involving routine tasks has fallen considerably. In a recent study, Autor and Dorn (2008) show that demand for low-skill service jobs, which pay low wages, has increased because these jobs involve mostly non-routine manual tasks requiring physical and interpersonal flexibility but little formal education. Spitz-Oener (2006) uses unique German survey data (four waves of the "Qualification and Occupational Career" survey from the late 1970s until the late 1990s) which include information on the tasks individual workers perform. She documents similar changes in tasks for Germany until the end of the 1990s as in the US. In particular, her analysis also shows a large increase in jobs involving non-routine manual tasks which tend to be low-wage jobs. As a big advantage, the German data allow to distinguish tasks from occupations. Even though the task approach is successful in explaining changes in the distribution of skill groups and the change in occupations, it is difficult to rationalize the fairly large stability of the wage structure in Germany until the mid 1990s based on this hypothesis. ${ }^{3}$ Therefore, it is of interest to investigate whether a task-based approach can rationalize the recent rise in wage inequality in Germany. For this, we use the same data as Spitz-Oener (2006) for the late 1990s and more recent data for 2006 in our analysis.

In contrast to the simple SBTC hypothesis, trends in wage inequality differ between the bottom and the top of the wage distribution. This has spurred interest in the so called polarization hypothesis. Manning (2004), Goos and Manning (2007), and Autor and Dorn (2008) argue that the task-based approach may also rationalize the empirical fact

\footnotetext{
${ }^{3}$ In a recent study, Black and Spitz-Oener (2007) extend the task-based approach to analyze the change in the gender wage gap between 1979 and 1999. They find that the change in task inputs explains partly the reduction of the gender wage gap. Moreover, their results confirm the polarization theory in the labor market regarding the growth of both low-skilled and high-skilled employment.
} 
that the share of low wage jobs involving non-routine tasks with very low skill input has increased. These jobs traditionally paid less than many of the routine jobs requiring higher skill input. This is the basis for the polarization hypothesis stating that technological change may result in a reduction of jobs in the middle of the wage distribution implying a disproportionate growth of both high wage and low wage jobs. Based on the falling demand for workers in middle occupations, one might expect that wage inequality falls at the bottom of the wage distribution and increases at the top of the wage distribution. Even though Goos and Manning (2007) find evidence for the growth of both low-wage and high-wage jobs, the polarization hypothesis can not rationalize that wage inequality did not fall at the bottom of the wage distribution. Autor and Dorn (2008) clarify that the polarization hypothesis may also be consistent with rising wage inequality at the bottom of the wage distribution, when the manual low-skill jobs at the bottom of the wage distribution exhibit very low productivity levels and the complementarities between goods produced by high-skilled workers and services in the low-skill jobs are not strong. ${ }^{4}$ For Germany, Dustmann et al. (2007) show that consistent with the polarization hypothesis, occupations at the top of the wage distribution experienced the largest wage growth and wage growth for the occupations in the middle of the wage distribution appears to be smaller than wage growth at the bottom of the wage distribution.

There exists only a scarce literature on job complexity and several definitions of the term coexist in the literature (Table 1 provides an overview of some recent studies). The literature distinguishes objective and subjective measures of job complexity. Objective measures rely on experts specifying job-complexity-categories and individuals being classified by their occupations, for example by the Dictionary of Occupational Titles (DOT) in the US (as used by Autor et al., 2003, and Sturman et al., 2005). The DOT characterizes 12000 job titles and measures job complexity by ordinal rating scales. Subjective measures of job complexity rely on self reported assessments by workers of the tasks performed in their jobs (as used by Valentine, 2000, Van Der Vegt et al., 2000 or SpitzOener, 2006). Ganzach and Pazy (2001) argue that an individual's perception is a valid measure for job complexity within occupation and that there exists a strongly positive relationship between objective and subjective measures. The subjective measure is based on responses to questions about the degree of the following seven job aspects: 'dealing with others, autonomy, feedback, opportunities for establishing friendship, opportunities to complete tasks, task identity and task variety.' For our empirical analysis, we define job complexity within a task-based approach to reflect the extent to which a job involves

\footnotetext{
${ }^{4}$ Note that Autor and Dorn (2008) find fairly high wage growth for low-skill service jobs in the US suggesting a high degree of complementarity with high-skilled jobs.
} 
different tasks and to which a worker is expected to switch between different tasks.

What is the impact of job complexity on wages? Grossberg and Sicilian (1999) estimate the relationship between on-the-job training, minimum wages, and wage growth. Job complexity is a proxy for labor force attachment and measures the number of weeks which an inexperienced new worker with the necessary education needs to be fully trained and qualified. The study finds a positive relationship between job complexity and starting wage. Job complexity shows a positive impact on on-the-job training which results in further wage growth. Van Ophem et al. (1993) model occupational choice where the utility of the worker depends positively upon the wage rate and negatively on job complexity. Job complexity, job difficulty, and job level are classified by job analysts, i.e. these are objective measures. The ordinal seven-stage scale (from level $1=$ 'very simple labor, requiring no consultation and which can be performed after a few days of experience' to level 7 = 'applied work on a scientific basis or purely scientific work') was produced by the Dutch Department of Labor and includes the work content, required skills, and the ability to acquire the necessary knowledge (see also Hartog and Vriend, 1990). In the model of Van Ophem et al. (1993) the wage rate is positively correlated with job complexity. The underlying assumption is that individuals request a compensation for higher job complexity. Gavrel (2007) develops a matching model where firms optimally choose job complexity. According to the model, the rise in unemployment could explain both increasing job complexity as well as low wages and low employment rates of lowskilled workers.

Our paper investigates recent changes in wage inequality in Germany for the time period 1999 to 2006. The contribution of our paper is threefold. First, this is the first study to analyze the most recent changes in wage inequality for full-time working males in Germany using the task-based approach of Autor et al. (2003) and Spitz-Oener (2006). Spitz-Oener (2006) uses the four waves of the "Qualification and Occupational Career" survey from the late 1970s to the late 1990s. A similar survey called "Working-PopulationSurvey" was redone in 2006 involving comparable task information. Our study here is the first study to make simultaneous use of the 2006 and the 1999 survey. This is a particularly interesting time period because wage inequality has been increasing. Institutional rigidities might have prevented an increase in wage inequality at the bottom of the wage distribution in Germany until the mid 1990s and, thus, the task-based approach has only been able to explain employment changes for this earlier time period (Spitz-Oener, 2006). Thus, it is of interest to analyze as to whether a tasked-based approach may rationalize the changes in wage inequality during the most recent time period when institutions did not prevent an increase in wage inequality at the bottom of the wage distribution in 
Germany. Furthermore, in response to the strong increase in unemployment Germany implemented major labor market reforms to increase the work incentives of the unemployed and to make labor market policy more effective (Fitzenberger, 2007) and unionization rates have been falling (Fitzenberger et al., 2006; Dustmann et al., 2007).

Second, in addition to the task categories used by Spitz-Oener (2006) for Germany, we also use two proxies for job complexity. Changing from routine to non-routine tasks is likely to increase job complexity because workers have to perform different tasks simultaneously and the necessity to responding flexibly to changing demands at jobs has increased. Thus, in addition to task assignments as defined by Autor et al. (2003) and Spitz-Oener (2006), we also use two proxies for job complexity. The first proxy is a summary measure simply involving the number of tasks individuals perform. The second proxy is a summary measure of the individuals responses to six questions regarding the repetitiveness of the tasks performed at work. We suggest a different operationalization of the five task categories used by Spitz-Oener (2006), which allows us to separately identify the wage effects of task assignment in those five task categories from our two proxies for job complexity.

Third, we perform a Blinder-Oaxaca type decomposition of the changes in the entire wage distribution between 1999 and 2006 into the separate effects of personal characteristics and task assignments. The decomposition is similar in spirit to a Machado and Mata (2005) type decomposition for quantile regression. We operationalize such a decomposition based on the estimation of heteroscedastic interval regressions for wages. In estimating the counterfactual wage distribution for 1999 personal characteristics and 2006 task characteristics, we suggest an extension of the Fairlie (2005) approach.

Our main results are as follows. In line with the literature, we find a noticeable increase of wage inequality between 1999 and 2006. The difference between the 80th and the 20th percentile of log wages increases by around 8 percentage points. Wage inequality increases by about the same extent both at the bottom and at the top of the wage distribution. The decomposition results show that the changes in personal characteristics explain some of the increase in wage inequality whereas the change in task assignments strongly works towards reducing wage inequality. The coefficient effect for personal characteristics works towards an increase in wage inequality at the top of the wage distribution. In contrast, the coefficient effect for the task assignments shows an inverse U-shaped pattern, i.e. the task coefficients change towards decreasing (increasing) wage inequality in the upper (lower) part of the wage distribution. Altogether, we have to conclude that the task-based approach can not explain the recent increase in wage inequality among male employees in Germany. In fact, task assignments have changed towards reducing wage inequality 
and the changes in task coefficients tend to reduce wage inequality at the top of the wage distribution. The change in task coefficients has only contributed to the increase of wage inequality at the bottom of the wage distribution. Only, the rise in wage inequality at the bottom of the wage distribution can be rationalized by a low degree of complementarity between low-wage jobs and high-wage jobs (Autor and Dorn, 2008).

The remainder of this paper is structured as follows: Section 2 describes the data. Section 3 discusses the estimation of heteroscedastic interval regressions for wages and develops the approach to decompose the changes in the wage distribution. Section 4 presents the empirical results. Section 5 concludes. The appendix includes further information on the data and detailed empirical results.

\section{Data}

The present study uses the BIBB/IAB Qualification and Occupational Career Survey ${ }^{5}$ for

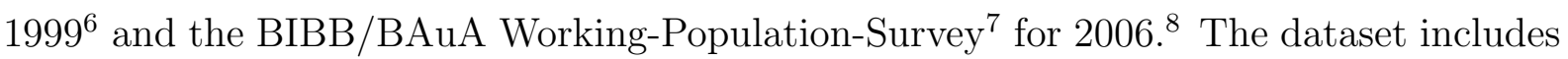
about 30,000 (20,000) respondents for the years 1999 (2006). The data include population weights to undertake a representative analysis of all employees in Germany. The great advantage of these data is that respondents are asked which tasks they actually carry out as well as which skill-requirements are demanded in their jobs.

We restrict our analysis to full-time working male German citizens who are between 25 and 55 years old. Considering that the labor participation rate is high among this group, we argue that the selection bias for employment/unemployment is rather small. This leaves us with a sample of 9,420 observations for 1999 and a sample of 6,348 observations for 2006, which includes employees and self-employed.

The data involve self-reported monthly earnings by intervals for the 1999 sample and actual earnings for the 2006 sample. For the 2006 sample, if an individual decides not to report earnings, that individual has the option to report when he/she earns above or below $€ 1,500$ per month. This concerns about $15 \%$ of all earnings observations and we include this information in our subsequent analysis.

\footnotetext{
${ }^{5}$ In German: Qualifikation und Berufsverlauf. This survey is conducted by the German Federal Institute for Vocational Training (In German: Bundesinstitut für Berufsbildung, BIBB) and the Research Institute of the Federal Employment Agency (In German: Institut für Arbeitsmarkt- und Berufsforschung).

${ }^{6}$ The study was carried out between 1998 and 1999. For simplicity, we refer to this two-year period as 1999 .

${ }^{7}$ In German: Erwerbstätigenbefragung. This survey is conducted by the German Federal Institute for Vocational Training (In German: Bundesinstitut für Berufsbildung, BIBB) and the Federal Institute for Occupational Safety and Health (In German: Bundesanstalt für Arbeitsschutz und Arbeitsmedizin, $\mathrm{BAuA}$ ).

${ }^{8}$ The study was carried out between 2005 and 2006. For simplicity, we refer to this two-year period as 2006 .
} 
As personal characteristics, we distinguish workers by age ${ }^{9}$ and by the three skill categories $^{10}$ :

low-skilled: without a vocational training degree

medium-skilled: with a vocational training degree ("Berufsausbildung")

high-skilled: with a degree from a University ("Hochschule") or a University of the Applied Sciences ("Fachhochschule")

We remark that skill upgrading seems to have taken place during that period: While the part of the low-skilled workers shrank from $9 \%$ to $5 \%$, the share of high-skilled workers rose by 4 ppoints to $22 \%$ in 2006 . Hence, the share of medium-skilled workers remained stable at about $73 \%$.

Furthermore, we define dummy variables variables for 20 different occupations, based on the list of 33 ocupations provided by the Federal Statistical office ${ }^{11}$, (see Statistisches Bundesamt, 1992), which are described in Table 2.

To operationalize the task categories, we follow Spitz-Oener (2006) as closely as possible $^{12}$ and aggregate ${ }^{13}$ the 14 different tasks reported in the data to the five task measures suggested by Autor et al. (2003) (see Table 5 for the aggregation). The five task measures (indexed by $\mathrm{j}$ ) are $\mathrm{j}=1$ : non-routine analytic tasks, $\mathrm{j}=2$ : non-routine interactive tasks, $\mathrm{j}$ $=3$ : routine cognitive tasks, $\mathrm{j}=4$ : routine manual tasks, and $\mathrm{j}=5$ : non-routine manual tasks $^{14}$. The task measures are calculated for individual $i$ in cross-section $t$.

For our empirical analysis, we use two alternative definitions for the task indices. The first task-index is the definition used by Spitz-Oener (2006), henceforth SO-Task-Index, which is given by

$$
S O_{i j t}=\frac{\text { number of activities in category } \mathrm{j} \text { performed by } \mathrm{i} \text { in cross section } \mathrm{t}}{\text { total number of activities in category } \mathrm{j} \text { at time } \mathrm{t}}
$$

This definition measures the share of activities (tasks) a worker reports to perform among all activities (tasks) of type $j$. This definition mixes the distribution of time a worker spends on each task with the total number of tasks performed. Since the latter

\footnotetext{
${ }^{9}$ Pointwise estimates indicate that the working population has aged from 40 years in 1999 to 42 years 2006 on average.

${ }^{10}$ In order to make our study comparable to the existing literature we decide to implement the prevalant education categories.

${ }^{11}$ In German: Statistisches Bundesamt.

${ }^{12}$ The distribution of the tasks proposed by Spitz-Oener (2006), who uses the first four available BIBB/IAB surveys until 1999 differs slightly from ours. These differences are due to the fact that some tasks reported in the past do not exist any more in the data used here.

${ }^{13}$ Note that aggregation of the single task categories helps to reduce possible measurement error and allows at the same time to capture the main structure of the tasks carried out by the individuals.

${ }^{14}$ Playing around with the categorization of the tasks in an economically meaningful sense reveals that our results are robust towards changes in the categorization.
} 
reflects job complexity, we would like to distinguish these two aspects. Therefore, we propose an alternative definition of the task-index, henceforth AFL-Task-Index, ${ }^{15}$ which measures the distribution of tasks reported in the five task categories. This AFL-TaskIndex is given by

$$
A F L_{i j t}=\frac{\text { number of activities in category } \mathrm{j} \text { performed by } \mathrm{i} \text { in cross section } \mathrm{t}}{\text { total number of activities performed by } \mathrm{i} \text { over all categories at time } \mathrm{t}}
$$

Our new task-index gives the share of reported tasks in category $j$ among all categories reported by worker $i$. We take this as an approximation of the share of working time this worker uses to perform tasks in category $j$. In contrast to the SO-Task-Indices, the AFLTask-Indices sum up to one for each individual and therefore one index has to be omitted as covariate in a regression with an intercept.

Tables 6 and 7 show the distribution of the two different definitions of the task indices, the SO-Task-Index and the AFL-Task-Index, respectively, for the two survey years. We find remarkable changes in the two task indices between 1999 and 2006. The SO-TaskIndex indicates that the non-routine analytic and routine cognitive task indices increase by 12.2 and 8.8 ppoints, respectively, whereas the task indices for non-routine interactive (-1 ppoint), routine manual (-5.4 ppoints) and non-routine manual (-7.9 ppoints) decline. Furthermore, the SO-Task-Index shows that for the low-skilled worker a rise in nonroutine analytic and routine cognitive tasks took place, while the non-routine manual tasks decline. For high-skilled workers, we find an increase of non-routine analytic tasks and a large decrease of non-routine manual tasks. The impact of the non-routine manual tasks is unchanged for the low-skilled workers, whereas these tasks in the med skilled group also decreased. For the med-skilled worker have the routine cognitive task the largest impact, which also increased since 1999. Furthermore, the non-routine analytic tasks documented a rise in the med-skilled group, too. Overall, the largest changes of the SO-Task-Index are the rise of non-routine-analytic tasks in all skilled groups and the decreasing of non-routine manual tasks in the high-skilled group. The AFL-TaskIndex indicates similar changes but the decline of routine manual tasks is stronger than the decline of non-routine manual tasks. For the low-skilled, it is observed that routine manual tasks strongly decrease. In contrast to the SO-Task-Index one can find a higher increase of the non-routine analytic task in the high-skilled than in the low-skilled group. Remarkable regarding the described development of the tasks is the contrast to the taskbased framework or rather the changes of the tasks from 1979 until 1999, detailed described in Spitz-Oener (2006). Autor et al. (2003) and Spitz-Oener (2006) determined a large

\footnotetext{
${ }^{15} \mathrm{AFL}$ stands for the first letters of the authors' surnames and is not to be confounded with any US union organization or sports organization.
} 
increase in jobs involving non-routine manual tasks and our data shows a large decrease of non-routine manual tasks between 1999 and 2006. Furthermore Spitz-Oener (2006) showed, that routine cognitive tasks strongly decreased until 1999, whereas our results documenting an increase of these tasks from 1999 until 2006. This discovered opposing trend in the development of the routine cognitive and non-routine manual task categories is very notable. Furthermore the non-routine analytic (increase) and the routine manual (decrease) categories stay in trend. The increasing development of non-routine interactive tasks came to a stop.

The SO-Task-Index implicitly takes account of job complexity regarding the number of tasks performed. If the number of tasks increases then the sum of the SO-Task-Indices across the five categories grows as well. However, this increase is weighted by the total number of tasks in category $j$. To account for job complexity when using our AFL-TaskIndex, we define NJC as the total number of activities (tasks) reported by a worker and use NJC as a measure for job complexity. Note that NJC corresponds to the denominator in equation (7).

As a second indicator of subjective job complexity, we define the variable SJC which contains information about how workers rate their job requirements. Specifically, workers are asked, (i) if the procedures they carry out in their job are described in detail, (ii) if the procedures in their job are very often of the same nature, (iii) if it happens regularly that new tasks are posed which have to be thought through beforehand, (iv) if existing procedures in their jobs have to be improved, (v) if things are demanded the individual has not been trained in and (vi) if it is demanded that different tasks are to be carried out at the same time. The individual either may respond that this is always or often the case or that this is rather seldom. Hence we create binary variables taking the values 1 in the former case and 0 otherwise. Individuals who respond affirmatively to the first two questions hold rather monotone jobs compared to respondents who respond affirmatively to questions three to six. ${ }^{16}$ We define dummy variables for affirmative answers (combining the categories always and often) to the six questions on job requirements which we denote by $j r_{1}$ to $j r_{6}$. Then, our subjective indicator for job complexity SJC is defined by

$$
S J C_{i}=(-1) j r_{1}+(-1) j r_{2}+j r_{3}+j r_{4}+j r_{5}+j r_{6}
$$

which sums up the number of affirmative answers for questions 3 to 6 and subtracts the number of affirmative answers to questions 1 and 2. The higher the value of SJC, the less monotone the worker views his job.

\footnotetext{
${ }^{16} \mathrm{~A}$ simple correlation analysis reveals that the first two are positively correlated with each other and negatively correlated with the last four questions. Again the last four question show positively correlated answers. Note again that the aggregation helps to diminish possible measurement error.
} 
Table 8 reports the descriptive statistics for SJC. As to be expected, SJC increases with the skill level. Between 1999 and 2006, SJC increases and the increase is strongest for low-skilled workers. Table 9 sums up the descriptive statistics for NJC. Qualitively NJC and SJC show the same movements between 1999 and 2006, with the exception that NJC actually falls for the high-skilled workers. The reason for this exception is probably, that the high-skilled already reached a high degree of complexity, so that there only a marginal rise, but also little variation downwards within a high complexity degree is thinkable. The potential to increase the complexity degree of the job is certainly higher in low-skilled jobs. Furthermore technical improvements, which reduced the working time for manufacturing processes and therefore allows to do more things in same time, you can mainly find in low-skilled jobs.

As one additional specific task variable, we use the dummy variable PC-use, which indicates whether a person uses a personal computer in his job on a regular basis. It is often argued that skilled biased technical change has affected the workplace most strongly through the use of computers, see Autor et al. (2003).

\section{Econometric Approach}

We estimate a location scale model for wages where both the mean log wage and the variance of log wages depends upon observed covariates. This is similar in spirit to estimating quantile regressions of wages allowing for wage dispersion to differ by covariates. Because all wages in 1999 and some of the wage information in 2006 involve only interval information, we estimate heteroscedastic interval regressions for wages. We use our model estimates to simulate both the actual, unobserved wage distributions and counterfactual wage distributions to perform a Blinder-Oaxaca-type decomposition analysis of the changes in the wage structure between 1999 and 2006, similar in spirit to a Machado and Mata (2005) type decomposition for quantile regression. Our decomposition analysis distinguishes the contribution of personal characteristics $P$ from the contribution of task variables $T$. We suggest to model the link between the two sets of variables explicitly when estimating the counterfactual distribution of wages when personal characteristics are taken from one year and task variables are taken from another year. Our approach extends upon the Fairlie (1999) and Fairlie (2005) decomposition analysis for nonlinear estimation problems. We emphasize that a credible decomposition analysis has to account for the link between the two sets of variables and that this requires that the researcher has to be very specific when defining the counterfactuals. In the decomposition analysis, we specifically address the question what would have been the wage structure in 2006 if 
we still had the 1999 sample of workers but if some or all labor market conditions are as in 2006. This question motivates our particular choice of the sequence of counterfactuals.

\subsection{Estimated Model}

We specify the $\log$ hourly wage $\log \left(w_{i}\right)$ of individual $i$ to be normally distributed where both mean and variance depend upon the observed covariates $X_{i}=\left(P_{i}, T_{i}\right)$ comprising personal characteristics $P_{i}$ and task variables $T_{i}$. Specifically, we assume

(4) $\log \left(w_{i}\right)=\beta_{0}+X_{i}^{\prime} \beta_{1}+\sigma_{i} \cdot \epsilon_{i}$

where the random variable $\epsilon_{i}$ is independent across observations $i$ and it is assumed to follow a standard normal distribution. The expectation of log wages conditional on $X_{i}$ is given by $E\left(\log \left(w_{i}\right) \mid X_{i}\right)=\beta_{0}+X_{i}^{\prime} \beta_{1}$. We allow the conditional wage dispersion to vary with observed covariates by specifying the log standard deviation as a linear function of covariates $X_{i}$

$$
\sqrt{\operatorname{Var}\left(\log \left(w_{i}\right) \mid X_{i}\right)} \equiv \log \left(\sigma_{i}\right)=\gamma_{0}+X_{i}^{\prime} \gamma_{1}
$$

We estimate the parameters of the wage model $\beta=\left(\beta_{0}, \beta_{1}\right)$ and $\gamma=\left(\gamma_{0}, \gamma_{1}\right)$ by Maximum Likelihood taking account of the fact that we may only have the information that the individual wage lies in some interval whose endpoints differ by observation $i$. Basically, we estimate a heteroscedastic interval regression allowing for some observations with exact wage information. Moreover, we use population weights $g_{i}$ for weighted estimation provided by the data.

Define the indicator function $I_{i}=1$ if only internal information on wages is available and $I_{i}=0$ if the actual wage is observed. When $I_{i}=1$, we only know that $w_{i}$ lies in the interval $\left[a_{i}, b_{i}\right] . a_{i}=0$ represents the case where we only observe some upper bound $b_{i}<\infty$ for the wage. $b_{i}=\infty$ represents the case where we only observe some positive lower bound $a_{i}>0$ for the wage. Even though there are fixed earnings intervals reported in the data, the intervals $\left[a_{i}, b_{i}\right]$ for hourly wage $w_{i}$ have index $i$ because the individuals differ in their reported hours of work.

To estimate the model parameters $(\beta, \gamma)$, our maximum likelihood estimator maximizes the weighted sum $\sum_{i} g_{i} \log \left(L_{i}\right)$ where the individual contributions to the likelihood function are given by

$$
\text { (6) } \begin{aligned}
L_{i} & =\left[\frac{1}{\sigma_{i}} \varphi\left(\frac{\log \left(w_{i}\right)-\beta_{0}-X_{i}^{\prime} \beta}{\sigma_{i}}\right)\right]^{I_{i}=0} \\
\cdot & {\left[\Phi\left(\frac{\log \left(b_{i}\right)-\beta_{0}-X_{i}^{\prime} \beta}{\sigma_{i}}\right)-\Phi\left(\frac{\log \left(a_{i}\right)-\beta_{0}-X_{i}^{\prime} \beta}{\sigma_{i}}\right)\right]^{I_{i}=1} }
\end{aligned}
$$


where $\sigma_{i}=\exp \left(\gamma_{0}+X_{i}^{\prime} \gamma_{1}\right)$ and $g_{i}$ are the population weights provided by the data. By abuse of notation for the limit case $b_{i} \rightarrow \infty$ and $a_{i}=0$, we take the first term in brackets in the second line (for the case $I_{1}=1$ ) to be equal to one for $b_{i}=\infty$ (no upper bound of wage interval). Analogously for $a_{i}=0$, we take the second term to be equal to zero for $a_{i}=0$ (no lower bound of wage interval).

Note that the interval regression commands in econometric software packages such as TSP or Stata do not simultaneously allow for the combination of weighting, heteroscedasticity, and some of the wages not being interval coded. Therefore, we programmed the estimator in TSP.

\subsection{Simulation and Decomposition}

Based on our estimates for the model parameters, we are able estimate the unobserved actual unconditional wage distribution of $\log \left(w_{i}\right)$ using a simulation approach. This approach is also being applied in order to estimate the counterfactual distribution used in our subsequent decomposition analysis. Analogous to a Machado and Mata (2005) simulation of the unconditional wage distribution based on quantile regression estimates, we draw a random $\epsilon_{i}$ for each observation $i$ from a standard normal distribution and use the estimated parameters $(\hat{\beta}, \hat{\gamma})$ replacing the true parameters to simulate a wage sample $w_{i}^{*}$ according to equation (4). Then, we calculate empirical quantiles $q_{\theta}$ of the weighted distribution of simulated wages using weights $g_{i}$ at the 19 quantiles $\theta=.05, .1, .15, \ldots, .95$. In our application it turns out, that there is a sizeable simulation error in doing so. ${ }^{17}$ Therefore, we simulate 10 samples for each case and then take the average of the 10 corresponding quantile estimates as our estimates for the unconditional distribution of wages.

We estimate the unconditional wage distribution both for the 1999 and the 2006 samples using model parameters $\alpha^{99}=\left(\hat{\beta}^{99}, \hat{\gamma}^{99}\right)$ and $\alpha^{06}=\left(\hat{\beta}^{06}, \hat{\gamma}^{06}\right)$, respectively, obtained separately for the two years. ${ }^{18}$ We denote the quantiles for the two distributions by

$$
q_{\theta}^{99}\left(P^{99}, T^{99}, \alpha_{0}^{99}, \alpha_{1, P}^{99}, \alpha_{1, T}^{99}\right) \quad \text { and } \quad q_{\theta}^{06}\left(P^{06}, T^{06}, \alpha_{0}^{06}, \alpha_{1, P}^{06}, \alpha_{1, T}^{06}\right)
$$

respectively. This involved notation is key to develop the separate steps in our decomposition analysis below. The superscript $j=99,06$ in $q_{\theta}^{j}($.$) reflects the sample and the$ weights used for simulation. The first two arguments $P^{j}, T^{j}$ indicate which sample of personal $(\mathrm{P})$ and task $(\mathrm{T})$ characteristics are used for the simulation. The arguments

\footnotetext{
${ }^{17}$ Note that one simulation of a wage distribution is just one sample draw in a simulation based on our estimated model for our initial sample.

${ }^{18}$ To simplify the notation, we omit the hats for the $\alpha$ 's even though these are estimates.
} 
$\alpha_{0}^{j}, \alpha_{1, P}^{j}, \alpha_{1, T}^{j}$ denote the sets of coefficients used in the simulation for the intercepts, the slope coefficients for the personal characteristics, and the slope coefficients for the task characteristics, respectively. Note that each argument comprises both the coefficients for the mean $\beta$ and the standard deviation $\gamma$.

To investigate the change in the wage distribution between 1999 and 2006, we analyze the quantiles differences

$$
\Delta_{\theta}^{06 / 99}=q_{\theta}^{06}\left(P^{06}, T^{06}, \alpha_{0}^{06}, \alpha_{1, P}^{06}, \alpha_{1, T}^{06}\right)-q_{\theta}^{99}\left(P^{99}, T^{99}, \alpha_{0}^{99}, \alpha_{1, P}^{99}, \alpha_{1, T}^{99}\right)
$$

Our decomposition analysis will separately analyze the contribution of each of the five arguments of the simulated quantiles to statistically explain $\Delta_{\theta}^{06 / 99}$. We normalize all covariates used for the estimation by using deviations from their corresponding weighted average in 1999. This allows a meaningful decomposition of the impact of the different sets of covariates and the aggregate trends given by the changes in the intercepts. Note that this normalization corresponds to a particular sequence of counterfactuals wage distribution.

The particular sequence of counterfactuals we analyze starts by addressing the question what would be the wage distribution if we had the 1999 sample of individuals with their personal characteristics, we assigned them tasks as in 2006, and we rewarded their characteristics as in 2006 (i.e. we use 2006 coefficients). This tells us the wage distribution in 2006 had we still the 1999 individuals being exposed to the 2006 labor market. The second counterfactual involves the 1999 individuals and task assignment being rewarded as in 2006. To decompose the coefficient effect of personal characteristics from tasks, we normalize all regressors around their 1999 weighted means and first analyze as third counterfactual the wage distribution implied by 1999 intercepts and 2006 slope coefficients. This allows to separate the general trend in the wage distribution from the effects of the slope coefficients. The fourth counterfactual changes to 1999 coefficients of personal characteristics and the 1999 wage distribution finally also involves the 1999 coefficients of tasks.

Formally, the decomposition $\Delta_{\theta}^{06 / 99}$ into five components works as follows. The first two decomposition terms involve the characteristic effects regarding the contribution of the changes in personal characteristics and task characteristics. The remaining three concern the coefficient effects for the intercepts, the personal characteristics, and the task characteristics. Our decomposition proceeds by the sequence of arguments in the simulated quantiles in equation (7). For each simulation of counterfactuals, we again take the averages of the quantiles over 10 simulations.

The first component $\Delta_{\theta}^{1}$ involves the effect of the changes in personal characteristics 
and is defined by

$$
\Delta_{\theta}^{1}=q_{\theta}^{06}\left(P^{06}, T^{06}, \alpha_{0}^{06}, \alpha_{1, P}^{06}, \alpha_{1, T}^{06}\right)-q_{\theta}^{99}\left(P^{99}, T^{06}, \alpha_{0}^{06}, \alpha_{1, P}^{06}, \alpha_{1, T}^{06}\right)
$$

The second term involves the counterfactual wage distribution for the 1999 sample of individuals using 1999 weights (superscript 99) with the 1999 distribution of personal characteristics $P^{99}$. This counterfactual should give us the wage distribution for the 1999 sample of individuals with their personal characteristics had they been assigned the 2006 task distribution and did the 2006 coefficients apply. The operationalization of this intuitive definition is not straight forward. For a similar nonlinear decomposition problem, Fairlie (2005) discusses to assign the counterfactual task characteristics randomly (implicitly assuming independence between the different sets of characteristics) or based on the rank in the distribution of predicted outcomes. We think both strategies suffer from not taking account of the relationship between personal characteristics and task assignments. Thus, we suggest and use an alternative approach building on our interest in the counterfactual situation of a person in the 1999 sample when this person is assigned the 2006 tasks according to the way the labor market in 2006 works. To operationalize this notion, we estimate probits regressing the task dummy variables on personal characteristics for the 2006 sample mimicking the task assignment in 2006. We use these estimates to simulate the task assignment for our counterfactual by adding a random error term for each individual to the fitted latent variables and then determine the sign. ${ }^{19}$

The second component $\Delta_{\theta}^{2}$ involves the effect of the changes in task assignments and is defined by

$$
\Delta_{\theta}^{2}=q_{\theta}^{99}\left(P^{99}, T^{06}, \alpha_{0}^{06}, \alpha_{1, P}^{06}, \alpha_{1, T}^{06}\right)-q_{\theta}^{99}\left(P^{99}, T^{99}, \alpha_{0}^{06}, \alpha_{1, P}^{06}, \alpha_{1, T}^{06}\right)
$$

where the first term is the counterfactual used to define the first component and the second term involves the counterfactual wage distribution for the actual 1999 sample of individuals using both the personal characteristics $P^{99}$ and the task assignment $T^{99}$. The sum $\Delta_{\theta}^{1}+\Delta_{\theta}^{2}$ involves the full characteristics effect in a Blinder-Oaxaca type decomposition where the differences in characteristics is evaluated at 2006 coefficients.

The third component $\Delta_{\theta}^{3}$ involves the effect of the changes in the intercepts, i.e. the changes in the conditional expectation and the conditional variance for those individuals with average 1999 characteristics. This is defined by

$$
\Delta_{\theta}^{3}=q_{\theta}^{99}\left(P^{99}, T^{99}, \alpha_{0}^{06}, \alpha_{1, P}^{06}, \alpha_{1, T}^{06}\right)-q_{\theta}^{99}\left(P^{99}, T^{99}, \alpha_{0}^{99}, \alpha_{1, P}^{06}, \alpha_{1, T}^{06}\right)
$$

\footnotetext{
${ }^{19}$ Heinze (2008) uses a conceptually similar idea to decompose the gender wage gap into the components associated with personal characteristics and the components associated with firm characteristics. To construct the counterfactual with female personal characteristics and male firm characteristics, she uses nearest neighbor matching to assign the most similar male worker to a female worker in terms of her personal characteristics and then uses the firm characteristics of this matched male worker.
} 
We interpret $\Delta_{\theta}^{3}$ as the residual change (time trend) in the wage distribution which is unexplained by changes in characteristics or slope coefficients.

The fourth component $\Delta_{\theta}^{4}$ reflects the change in the coefficients of personal characteristics and is defined by

$$
\Delta_{\theta}^{4}=q_{\theta}^{99}\left(P^{99}, T^{99}, \alpha_{0}^{99}, \alpha_{1, P}^{06}, \alpha_{1, T}^{06}\right)-q_{\theta}^{99}\left(P^{99}, T^{99}, \alpha_{0}^{99}, \alpha_{1, P}^{99}, \alpha_{1, T}^{06}\right)
$$

The last component $\Delta_{\theta}^{5}$ reflects the change in the coefficients of task characteristics and is defined by

$$
\Delta_{\theta}^{5}=q_{\theta}^{99}\left(P^{99}, T^{99}, \alpha_{0}^{99}, \alpha_{1, P}^{99}, \alpha_{1, T}^{06}\right)-q_{\theta}^{99}\left(P^{99}, T^{99}, \alpha_{0}^{99}, \alpha_{1, P}^{99}, \alpha_{1, T}^{99}\right)
$$

The sum $\Delta_{\theta}^{3}+\Delta_{\theta}^{4}+\Delta_{\theta}^{5}$ involves the full coefficient effect in a Blinder-Oaxaca type decomposition where the differences in coefficients is evaluated at 1999 characteristics coefficients.

The overall decomposition of the changes in the wage distribution between 1999 and 2006 can be summarized as

$$
\Delta_{\theta}^{06 / 99}=\underbrace{\underbrace{\Delta_{\theta}^{1}}_{\text {Personal }}+\underbrace{\Delta_{\theta}^{2}}_{\text {Task }}}_{\text {Characteristics }}+\underbrace{\Delta_{\theta}^{3}}_{\begin{array}{c}
\text { Residual } \\
\text { effect }
\end{array}}+\underbrace{\underbrace{\Delta_{\theta}^{4}}_{\text {Personal }}+\underbrace{\Delta_{\theta}^{5}}_{\text {Task }}}_{\text {Coefficients }}
$$

Note that our definition of counterfactuals focuses on the 1999 sample of individuals defined by their personal characteristics and their sample weights. Consequently, we also used the same simulated value of the random variable $\epsilon_{i}$ for all simulations in one run of the 10 simulations involved.

We report bootstrap standard errors on our decomposition estimates which take account of the sample variability of the estimated model parameters. To do so, we implement a parametric bootstrap and resample the model coefficients from their estimated asymptotic distribution estimated by maximum likelihood.

\section{Results}

We analyze the change in the distribution of hourly wages for full-time working males between 1999 and 2006. To present our empirical results, we proceed in three steps. First, we describe the changes in the wage distribution. Second, we present our estimated heteroscedastic interval regressions for wages. Third, we use our regression estimates to decompose the changes in the wage distribution. Our regression results are of descriptive nature as we only control for observable characteristics, i.e. we do not claim to estimate causal effects. 


\subsection{Descriptive Evidence}

To analyze the changes in inequality of hourly wages among full-time working males, we analyze percentile differences in log wages, namely the 80-20, the 80-50, and the 5020 differences. ${ }^{20}$ The $80-20$ difference is a measure of overall wage inequality, while the 80-50 and 50-20 differences reflect wage inequality at the top and at the bottom of the distribution, respectively. ${ }^{21}$

For the descriptive results in this section, we first impute the midpoints of the earnings interval that is given by the respondent for the survey carried out in 1999 and we use the actual earnings reported in 2006. ${ }^{22}$ These earnings data are divided by reported hours ${ }^{23}$ to obtain hourly wages. Then, we calculate the $20 \%$ quantile, the median and the $80 \%$ quantile of log hourly wages and report the differences between these quantiles. Note that we tend to underestimate wage inequality in both years because for 1999 the earnings data are interval coded and for 2006 we ignore those $15 \%$ of the respondents who do not report their actual earnings and who are likely to have fairly high earnings (see footnote 22).

Table 3 provides the inequality measures for both years. The overall 80-20 difference in 1999 is .57 and it increases to .64 in 2006, i.e. we observe an increase by 7 log ppoints. The increase in the upper part (80-50) amounts to 5 log ppoints (.34-.29) and in the lower part (50-20) to 2 log ppoints (.30-.28). For the reasons discussed above, these numbers may differ from our subsequent simulation results discussed in section 4.3. Figure 1 provides kernel-density estimates of the wage distribution. It shows that in 2006 the distribution is flatter and more dispersed than in 1999.

Wage inequality differs by skill level (low, medium, high). Whereas wage inequality among medium-skilled workers has remained stable over time, wage inequality among low-skilled and high-skilled workers has increased. Specifically, low-skilled workers experienced a strong increase in wage inequality: we find evidence of an overall change of 16 log ppoints which is mainly driven by an increase of $14 \log$ ppoints at the top of wage distribution. High-skilled workers experienced a rise in overall wage inequality of $4 \mathrm{log}$

\footnotetext{
${ }^{20}$ For our analysis only full-time working men are taken into account that are between 25 and 55 years old, whereas working full-time is defined as working more than 25 hours per week. Furthermore, only German citizens employed in West Germany are considered. Finally individuals that respond that they work more than 71 hours per week are excluded from the analysis, as we consider this answer as not being reasonable.

${ }^{21}$ We focus here on the $20 \%, 50 \%$, and $80 \%$ quantiles as being respresentative for the wage distribution. The simulation results in section 4.3 provides more detailed graphical evidence, which is likely to be more reliable for reasons discussed below. Note that the statistical uncertainty increases at more extreme quantiles.

${ }^{22}$ About $15 \%$ of the respondents in the survey carried out in 2006 only respond whether their gross monthly earnings is below or above $€ 1500$ and $90 \%$ in this group report it to be above. As we cannot impute reasonable values for these individuals, they are excluded in this descriptive part.

${ }^{23}$ Over $90 \%$ of the respondents state that they work between $35 \mathrm{~h}$ and $55 \mathrm{~h}$ per week.
} 
ppoints percentage points which is associated with a similar increase in inequality both at the bottom and at the top of the wage distribution.

\subsection{Parameter Estimates}

Table 10 to Table 17 provide the different parameter estimates of the heteroscedastic interval regressions for log wages. The upper part of the tables shows the parameter estimates for the conditional expectations (mean log wages) and the lower part shows the parameter estimates for heteroscedasticity. We have estimated four different specifications for each of the two survey years resulting in eight separate estimates reported. The specifications differ as to whether we used the AFL-Task-Indices or the SO-Task-Indices (see section 2) and as to whether occupations are used as additional covariates in the regression. In the following, we treat occupation as part of the personal characteristics to separate the reported occupation from the reported task information.

Table 10 and Table 11 contain the parameter estimates for the two years 1999 and 2006 without occupations and our proposed AFL-Task-Indices $\left(A F L_{1}-A F L_{4}\right)$. These specifications also include the covariate NJC (sum of reported tasks) as one measure for job complexity. It is notable that the estimated parameter in the heteroscedasticity part for computer use shifts from about -.02 and being insignificant to -.09 in the second survey and now being highly significant. This can be interpreted as a wage smoothing effect of computer use. Using a computer also seems to be associated with higher average wages in 2006 than in 1999, as the parameter estimates grow over time (.15 versus .12). Considering the estimated parameters of AFL-Task-Indices, ${ }^{24}$ we observe that for this first specification all of them are less rewarded in 2006 than during the first period. While the data of the 1999 survey yields positive and significant values for all estimates of our taskmeasures, they drop dramatically in 2006. The measures for routine cognitive $\left(A F L_{3}\right)$ and routine manual $\left(A F L_{4}\right)$ tasks become even negative, though not being significant anymore. The objective measure for job complexity $(N J C)$ also seems to have a negative but not significant effect on wages, whereas the positive coefficient of subjective job complexity $(S J C)$ increases over time, though not significantly so.

We now compare the specification using our AFL-Task-Indices without conditioning on the different occupations with the specification conditioning on occupations, for which the results are shown in Table 12 and Table $13 .{ }^{25}$ The large positive effect of computer use is captured to a large extent by the occupations. To our surprise, the coefficient estimates for the AFL-Task-Indices change only to a small extent compared to the specification

\footnotetext{
${ }^{24}$ The category non-routine manual is the left-out category

${ }^{25}$ Occupational category 13 Painter, vanisher, unskilled worker is the left-out category.
} 
without occupation and we see similar changes in these coefficients over time. The estimated effects of NJC are basically not affected by conditioning on occupations. SJC still shows a positive effect on wages even after conditioning on occupations but its effect is reduced. Overall, our results suggest that a large part of the information in the task variables is not captured by occupations.

Comparing the specifications using the AFL-Task-Indices with the specifications using the SO-Task-Indices proposed by Spitz-Oener (2006) $\left(\mathrm{SO}_{1}-S O_{5}\right)$, we find that the estimates for the personal characteristics do not differ much. This indicates the robustness of our model to employing the task-indices proposed by Spitz-Oener (2006) and our task-indices. However, our approach allows to separately estimate the effects of job complexity as measured by NJC.

Regarding the specification without occupations the parameter estimates for the SOindices suggest that carrying out non-routine analytic tasks and non-routine interactive tasks is better rewarded in 2006 than in 1999, whereas routine tasks are less rewarded. This result is not robust against considering occupations though, since for this specification the estimates suggest that all tasks but the non-routine manual tasks are less rewarded in 2006 than in 1999. This finding may indicate an additional advantage of our proposed measure, since the results are robust for the specifications using the AFLindices.

Low-skilled and high-skilled ${ }^{26}$ workers are likely to experience quite different life-cycle profiles in wages. Results in Antonczyk (2007), Fitzenberger (1999), and Dustmann et al. (2007) support this hypothesis. Therefore, we interact our indicator variables for lowskilled and high-skilled workers with the variables age and age2. The parameter estimates for these interaction terms show significant differences between medium-skilled and highskilled workers whereas the age profile do not differ significantly between low-skilled and medium-skilled workers. The age profiles for high-skilled workers prove steeper than those for the other two skill groups.

For all specifications the results indicate that age shows less of a wage smoothing effect in 2006 than in 1999. Moreover the estimates show that being low-skilled or high-skilled in 2006 results in a higher wage dispersion in 2006 than in 1999, which is in line with what was shown by the unconditional descriptive statistics. Finally the parameter estimates for the measures of job complexity indicate that wage dispersion is positively correlated with the number of tasks carried out and this effect is rather stable for the two observed years. Subjective job complexity seems to become more "wage-smoothing" over the periods, these results are not always significant though.

\footnotetext{
${ }^{26}$ Medium-skilled workers are our left-out category.
} 


\subsection{Decomposition Results}

Our decomposition results are depicted in Figures 2 to $5^{27}$ which show overall wage growth between 1999 and 2006 by the quantiles of the unconditional wage distribution and the decomposition of wage growth according to the approach outlined in section 3.2. The changes of our measures for wage inequality between 1999 and 2006 are depicted with 95\%-confidence bands. ${ }^{28}$ In addition to the graphical evidence, Tables 18 to 21 provide specific numbers for the decomposition of the 80-20, 80-50, and 50-20 quantile differences. Depending on the specification employed we measure an increase of the overall wage dispersion, measured as the 80-20 difference ranging between 7.7 and 8.5 log ppoints. These differences reflect the possible estimation and specification error for the different estimated model. In contrast to the results reported in section 4.1, Tables 18 to 21 show that the increase in wage inequality in the lower part of the distribution (50-20) is slightly higher (4.2 to 4.6 log ppoints) than the increase in the upper part (3.2 to 3.9 log ppoints). Because the results reported in section 4.1 do not use the full variation of the data, we put more trust in the range of values obtained by our simulation approach. Thus, we conclude that the increase in wage inequality at the bottom of the distribution has been at least as large as at the top of the distribution.

We now discuss the results of our decomposition analysis. The changes in the personal characteristics (Char. P) contribute about 2-3 log ppoints to the increase in the 80-20 differential. Controlling for occupation as part of the personal characteristics somewhat reduces these figures, i.e. the change in occupation has slightly worked against an increase in inequality. The contribution of personal characteristics is larger at the top of the wage distribution (the figures for 80-50 are larger than for 50-20) and this difference is more pronounced in the model with occupations.

The contribution of changes in the task characteristics (Char. T) works in opposite direction, i.e. the changes in tasks work towards reducing wage inequality. This effect is almost uniform across the wage distribution (Figures 2 to 5), i.e. it works both towards reducing inequality at the bottom and at the top of the distribution. All reported effects are highly significant. The changes in the task characteristics work towards a reduction of the 80-20 differential by 3.3-4.1 log ppoints. The effect is reduced in absolute value when controlling for occupations which corresponds to the observation above that the positive effect on inequality of changes in the personal characteristics is mitigated when occupations are controlled for.

The coefficient effect of the personal characteristics (Coef. P) clearly contributes to

\footnotetext{
${ }^{27}$ Note that we use different domains for the vertical axis in order to better display the results.

${ }^{28}$ We employ a parametric bootstrap with 500 repetitions for inference.
} 
the rising wage inequality at the top of the wage distribution: the effect - measured by changes in the 80-50 differential - ranges from 1 to $1.5 \log$ ppoints. The effect in the lower part is only significant - and only marginally so - for the specification using the SO-Task-Indices together with occupations where it amounts to .8 log ppoints.

The task coefficient effect (Coef. T) shows a significant inverted U-shape. This indicates that this coefficient effect works towards lower inequality at the top of the wage distribution and towards higher inequality at the bottom of the wage distribution. The significant point estimates for the different specifications lie between 1 and 1.6 log ppoints for the lower part and between -1.5 and -.9 log ppoints in the upper part. If task coefficient are interpreted as prices (rewards for performing such tasks in terms of higher wages), the polarization hypothesis of Goos and Manning (2007) would predict a U-shaped pattern with wages both at the top and at the bottom of the distribution growing relative to the middle of the distribution because of increasing demands for tasks in both tails. However, as pointed out in the introduction, the model of Autor and Dorn (2008) can rationalize increasing wage dispersion at the bottom of the wage distribution in light of the polarization hypothesis by a low degree of complementarity between low-wage jobs and high-wage jobs.

Even though there are significant contributions of the substantive coefficient effects discussed above and the characteristics effects, the unexplained component (i.e. the effect of the changes in intercepts when we define covariates as deviations from their 1999 means, see section 3) is about the same as the overall change in the wage distribution. This holds almost exactly for the models not controlling for occupations. The unexplained component is somewhat reduced (especially for the 50-20 differential) when we control for occupations.

\section{Conclusions}

This paper provides an empirical analysis of recent changes in the German wage structure for the time period 1999 to 2006 . We analyze the changes in wage inequality for full-time working males in Germany using a task-based approach similar to Autor et al. (2003) and Spitz-Oener (2006). The results are based on more recent survey data for Germany than used by Spitz-Oener (2006), who builds on the data until 1999. In addition to the task categories used by Spitz-Oener (2006) for Germany, we also use two proxies for job com-

plexity. Furthermore, we perform a Blinder-Oaxaca type decomposition of the changes in the entire wage distribution between 1999 and 2006 into the separate effects of personal characteristics and task assignments. We operationalize such a decomposition based on 
the estimation of heteroscedastic interval regressions for wages. In estimating the counterfactual wage distribution for 1999 personal characteristics and 2006 task characteristics, we suggest an extension of the Fairlie (2005) approach.

In line with the literature, our paper finds a noticeable increase of wage inequality between 1999 and 2006. The difference between the 80th and the 20th percentile of log wages increases by around 8 percentage points, with the increase being about the same both at the bottom and at the top of the wage distribution. The decomposition results show that the changes in personal characteristics explain some of the increase in wage inequality, whereas the changes in task assignments and occupations strongly work towards reducing wage inequality. The coefficient effect for personal characteristics works towards an increase in wage inequality at the top of the wage distribution. In contrast, the coefficient effect for the task assignments shows an inverted U-shaped pattern, i.e. the task coefficients change towards reducing (increasing) wage inequality at the top (bottom) of the wage distribution.

Overall, we have to conclude that the task-based approach can not explain the recent increase in wage inequality among male employees in Germany. Only at the bottom of the wage distribution, the change in task coefficients has contributed to the increase in wage inequality. Thus, wages for the tasks demanded in low wage jobs have fallen disproportionately over time. This finding confirms the assessment in Goos and Manning (2007) (sections VII-VIII) that the polarization hypothesis derived from the task-based approach of Autor et al. (2003) can not explain the rising wage inequality at the bottom of the wage distribution - except for the small part of the rise in wage inequality at the bottom, which can be attributed to the task coefficient effect. The latter can be rationalized in light of the polarization hypothesis by a low degree of complementarity between low-wage jobs and high-wage jobs (Autor and Dorn, 2008). Furthermore, our findings suggest to analyze the impact of institutional changes, such as deunionization (see Dustmann et al., 2007) and the labor market reforms, as potential explanations for the recent increase in wage inequality. 


\section{References}

Acemoglu, D. (1998). "Why Do New Technologies Complement Skills? Directed Technical Change And Wage Inequality". The Quarterly Journal of Economics 113(4), 10551089.

Antonczyk, D. (2007). "Gender Wage differences in West Germany: A cohort Analysis". Discussion Paper, Albert-Ludwigs-University Freiburg.

Autor, D. and D. Dorn (2008). "Inequality and Specialization: The Growth of Low-Skill Service Jobs in the United States". Discussion Paper, MIT.

Autor, D., L. Katz, and M. Kearney (2008). "Trends in U.S. Wage Inequality: ReAssessing the Revisionists". Review of Economics and Statistics forthcoming.

Autor, D., F. Levy, and R. Murnane (2003). "The Skill Content of Recent Technological Change: An Empirical Exploration". The Quarterly Journal of Economics 118(4), 1279-1333.

Black, S. and A. Spitz-Oener (2007). "Explaining Women's Success: Technological Change and the Skill Content of Women's Work". NBER Working Paper 13116.

DiNardo, J., N. Fortin, and T. Lemieux (1996). "Labor Markets Institutions and the Distribution of Wages, 1973-1992: A Semiparametric Approach". Econometrica 64, 1001-1044.

Dustmann, C., J. Ludsteck, and U. Schönberg (2007). "Revisiting the German Wage Structure". IZA Discussion Paper 2685.

Fairlie, R. (1999). "The Absence of the African-American Owned Business: An Analysis of the Dynamics of Self-Employment". Journal of Labor Economics 17(1), 80-108.

Fairlie, R. (2005). "An Extension of the Blinder-Oaxaca Decomposition Technique to Logit and Probit Models". Journal of Economic an Social Measurement 30, 305-316.

Fitzenberger, B. (1999). "Wages and Employment Across Skill Groups: An Analysis for West Germany". Physica/Springer, Heidelberg.

Fitzenberger, B. (2007). "Nach der Reform ist vor der Reform? Eine arbeitsökonomische Analyse ausgewählter Aspekte der Hartz-Reformen". ZEW Discussion Paper 08-011.

Fitzenberger, B. and K. Kohn (2006). "Skill Wage Premia, Employment, and Cohort Effects: Are Workers in Germany all of the Same Type?". IZA Discussion Paper 2185. 
Fitzenberger, B., K. Kohn, and Q. Wang (2006). "The Erosion of Union Membership in Germany: Determinants, Densities, Decompositions". IZA Discussion Paper 2193.

Fried, Y., S. Melamed, and H. Ben-David (2002). "The joint effect of noise, job complexity, and gender on employee sickness absence: An exploratory study across 21 organizations - the CORDIS study". Journal of Occupational and Organizational Psychology 75, 131144.

Ganzach, Y. and A. Pazy (2001). "Within-occupation sources of variance in Incumbent Perception of Job Complexity". Journal of Occupational and Organizational Psychology 74, 95-108.

Gavrel, F. (2007). "Optimal Jobs Complexity in a Matching Model with Heterogenous Workers and Undirected Search". Cerene, University of Le Havre.

Gernandt, J. and F. Pfeiffer (2007). "Rising Wage Inequality in Germany". Journal of Economics and Statistics 227(4), 358-380.

Goos, M. and A. Manning (2007). "Lousy and Lovely Jobs: The Rising Polarization of Work in Britain". Review of Economics and Statistics 89, 118-133.

Grossberg, A. and P. Sicilian (1999). "Minimum Wages, On-the-Job Training, and Wage Growth". Southern Economic Journal 65(3), 539-556.

Hartog, J. and N. Vriend (1990). "Young Mediterraneans in the Dutch Labour Market: A Comparative Analysis of Allocation and Earnings". Oxford Economic Paper (42), $379-401$.

Heinze, A. (2008). "Beyond the mean gender wage gap: Decomposition of differences in wage distributions using quantile regression". Unpublished Manuscript, ZEW Mannheim.

Katz, L. and D. Autor (1999). "Changes in the Wage Structure and Earnings Inequality". Ashenfelter, O. and D. Card (eds), Handbook of Labor Economics. 3A, 1463-1555, North Holland, Amsterdam.

Kohn, K. (2006). "Rising Wage Dispersion, After All! The German Wage Structure at the Turn of the Century". ZEW Discussion Paper (06-031).

Machado, J. and J. Mata (2005). "Counterfactual Decomposition of Changes in Wage Distributions using Quantile Regression”. Journal of Applied Econometrics 20(4), 445465. 
Manning, A. (2004). "We can work it out: the impact of technological change on the demand for low-skill workers". Scottish Journal of Political Economy 51(5), 581-608.

Pekkarinen, T. and J. Vartiainen (2004). "Gender Differences in Job Assignment and Promotion on a Complexity Ladder of Jobs". IZA Discussion Paper (1184).

Spitz-Oener, A. (2006). "Technical Change, Job Tasks, and Rising Educational Demands: Looking Outside the Wage Structure". Journal of Labor Economics 24(2), 235-270.

Statistisches Bundesamt (1992). "Klassifizierung der Berufe - Systematisches und alphabetisches Verzeichnis der Berufsbennenungen". Metzler Poeschel: Stuttgart.

Sturman, M., L. Cashen, and R. Cheramie (2005). "The impact of Job Complexity and Performance Measurement on the temporal consistency, Stability, and Test-Retest Reliability of Employee Job Performance Ratings". Journal of Applied Psychology 90(2), 269-283.

Valentine, S. (2000). "A path analysis of gender, race, and job complexity as determinants of intention to look for work". Employee Relations 23,2, 130-145.

Van Der Vegt, G., B. Emans, and E. Van De Vliert (2000). "Team Members'Affective Responses to Patterns of Intragroup Interdependence and Job Complexity". Journal of Management 26(4), 633-655.

Van Ophem, H., J. Hartoog, and W. Vijverberg (1993). "Job Complexity and Wages". International Economic Review 34(4), 853-872. 


\section{Appendix}

Table 1: Definition of Job Complexity - Short Overview

\begin{tabular}{|c|c|c|c|}
\hline Study & $\begin{array}{l}\text { Object of } \\
\text { Investiga- } \\
\text { tion }\end{array}$ & Data & Definition of Job Complexity \\
\hline $\begin{array}{l}\text { Pekkarinen } \\
\text { and Var- } \\
\text { tiainen } \\
(2004)\end{array}$ & $\begin{array}{l}\text { Gender dif- } \\
\text { ferences in } \\
\text { the alloca- } \\
\text { tion of jobs } \\
\text { in respect } \\
\text { to the job } \\
\text { complexity }\end{array}$ & $\begin{array}{l}\text { Panel data of } \\
\text { Finnish met- } \\
\text { alworkers } \\
\text { (Confed- } \\
\text { eration of } \\
\text { Finnish In- } \\
\text { dustry and } \\
\text { Employers, } \\
1990-2000)\end{array}$ & $\begin{array}{l}\text { J.C. is measured with a grading system and the com- } \\
\text { plexity rating of the job-aspects was generated by some } \\
\text { experts. They estimate three criteria of job complex- } \\
\text { ity: 1)the duration to learn the tasks 2)degree of re- } \\
\text { sponsibility } 3 \text { )working conditions. Based on the grad- } \\
\text { ing of the job a accordingly wage for each job was } \\
\text { estimated. The higher the demand the higher the } \\
\text { occupation-related wage, which is then the variable to } \\
\text { measure job complexity and a job ladder was gener- } \\
\text { ated. }\end{array}$ \\
\hline $\begin{array}{l}\text { Fried et al. } \\
(2002)\end{array}$ & $\begin{array}{l}\text { Joint effect } \\
\text { of noise, job } \\
\text { complexity, } \\
\text { and gender } \\
\text { on employee } \\
\text { sickness } \\
\text { absence. }\end{array}$ & $\begin{array}{l}\text { Cordis (Car- } \\
\text { diovascular } \\
\text { Occupa- } \\
\text { tional Risk } \\
\text { Factors } \\
\text { Determi- } \\
\text { nation in } \\
\text { Israel) study } \\
\text { (1985-1987) }\end{array}$ & $\begin{array}{l}\text { J.C. is the average of estimated values for task com- } \\
\text { plexity (amount of elements, decisions, independence, } \\
\text { sophistication and skill level at the job) and task va- } \\
\text { riety of the employee's job through three independent } \\
\text { experts. Both items are measured with a } 4 \text {-point scale } \\
\text { with } 1 \text { indicating a very simple job and } 4 \text { implying a } \\
\text { very complex job and no job diversity till much diver- } \\
\text { sity respectively. }\end{array}$ \\
\hline $\begin{array}{l}\text { Valentine } \\
(2000)\end{array}$ & $\begin{array}{l}\text { The relation- } \\
\text { ship between } \\
\text { job com- } \\
\text { plexity and } \\
\text { intention } \\
\text { to look for } \\
\text { work, gender } \\
\text { and race }\end{array}$ & $\begin{array}{l}\text { National } \\
\text { Longitudinal } \\
\text { Survey of } \\
\text { Youth (US } \\
\text { Department } \\
\text { of Labor, } \\
1982 \text { ) }\end{array}$ & $\begin{array}{l}\text { J.C. is measured with using a reduced form of the "Job } \\
\text { Characteristics of Inventory" (developed by Sims et al., } \\
\text { 1976). The JCI measures an individuals rating in the } \\
\text { following five dimensions (three items each): Skill Va- } \\
\text { riety (extent of skill requirement), Task Identity (com- } \\
\text { plete a work from start to finish), Task Significance } \\
\text { (subjective estimation of the importance of the work), } \\
\text { Autonomy and Job Feedback. The values of these five- } \\
\text { scales are averaged by Valentine to get a index for (sub- } \\
\text { jective) J.C.. }\end{array}$ \\
\hline $\begin{array}{lr}\text { Van } & \\
\text { Der } & \text { Vegt } \\
\text { et } & \text { al. } \\
(2000) & \end{array}$ & $\begin{array}{l}\text { Effect from } \\
\text { J.C. on } \\
\text { individual } \\
\text { job/ team } \\
\text { satisfaction, } \\
\text { job/ team } \\
\text { commitment }\end{array}$ & $\begin{array}{l}114 \quad \text { em- } \\
\text { ployers at } \\
\text { a technical } \\
\text { consulting } \\
\text { firm }\end{array}$ & $\begin{array}{l}\text { Using a modified version of the Job Diagnostic Survey } \\
\text { with three items for each of the four dimensions: Skill } \\
\text { Variety, Task Significance, Task Identity and Auton- } \\
\text { omy. A overall job complexity scale is produced with } \\
\text { the subjective belief of individuals for each category. }\end{array}$ \\
\hline
\end{tabular}


Table 2: Occupational Categories

\begin{tabular}{|l|c|}
\hline & Category \\
\hline Agriculture and Forestry & 1 \\
\hline Mining, Mineral winning, Stonery, Material production & 2 \\
\hline Chemical industry & 3 \\
\hline Paper manufacturing, paper converting, printing, wood processing & 4 \\
\hline Metalworking industry & 5 \\
\hline Metal-structuring, Engineering & 6 \\
\hline Electrical engineering & 7 \\
\hline Apparel industry, leather production and processing & 8 \\
\hline Food industry & 9 \\
\hline Structural and civil engineering & 10 \\
\hline Lining, upholstering & 11 \\
\hline Wood- and plastic processing & 12 \\
\hline Painter, Vanisher, unskilled worker & 13 \\
\hline Chemists, Physicist, Mathematicans & 14 \\
\hline Technical engineers & 15 \\
\hline Merchants & 16 \\
\hline Service merchants & 17 \\
\hline Transport sector & 18 \\
\hline Organisation, Administration & 19 \\
\hline $\begin{array}{l}\text { Occupation of order and security, Artists, Health service, Social and educational } \\
\text { occupations, other service occupations }\end{array}$ & 20 \\
\hline
\end{tabular}

Table 3: Change in Wage Inequality from 1999 to 2006 (Hourly Wages - based on Interval Midpoints)

\begin{tabular}{|c|c|c|c|c|c|}
\hline \multicolumn{2}{|c|}{ 80-20 percentile } & \multicolumn{2}{|c|}{ 80-50 percentile } & \multicolumn{2}{|c|}{ 50-20 percentile } \\
\hline 1999 & 2006 & 1999 & 2006 & 1999 & 2006 \\
\hline \multicolumn{6}{|c|}{ All } \\
\hline 0.57 & 0.64 & 0.29 & 0.34 & 0.28 & 0.30 \\
\hline \multicolumn{6}{|c|}{ Low skilled } \\
\hline 0.55 & 0.71 & 0.25 & 0.39 & 0.30 & 0.33 \\
\hline \multicolumn{6}{|c|}{ Med skilled } \\
\hline 0.57 & 0.57 & 0.31 & 0.31 & 0.26 & 0.26 \\
\hline \multicolumn{6}{|c|}{ High skilled } \\
\hline 0.56 & 0.60 & 0.27 & 0.29 & 0.29 & 0.31 \\
\hline
\end{tabular}


Table 4: Personal Characteristics 1999 and 2006

\begin{tabular}{|c|c|c|c|c|}
\hline & \multicolumn{2}{|c|}{1999} & \multicolumn{2}{|c|}{2006} \\
\hline & Mean & Std.Dev. & Mean & Std.Dev. \\
\hline \multirow[t]{2}{*}{ Age } & 39.9 & 8.3 & 41.9 & 8.3 \\
\hline & \multicolumn{2}{|c|}{ Percentage } & \multicolumn{2}{|c|}{ Percentage } \\
\hline Low-skilled & \multicolumn{2}{|c|}{9} & \multicolumn{2}{|c|}{5} \\
\hline Medium-skilled & \multicolumn{2}{|c|}{74} & \multicolumn{2}{|c|}{73} \\
\hline High-skilled & \multicolumn{2}{|c|}{18} & \multicolumn{2}{|c|}{22} \\
\hline Occupational category 1 & \multicolumn{2}{|c|}{2} & \multicolumn{2}{|c|}{2.8} \\
\hline Occupational category 2 & \multicolumn{2}{|c|}{2} & \multicolumn{2}{|c|}{1.7} \\
\hline Occupational category 3 & \multicolumn{2}{|c|}{1.1} & \multicolumn{2}{|c|}{1} \\
\hline Occupational category 4 & \multicolumn{2}{|c|}{1.9} & \multicolumn{2}{|c|}{2.7} \\
\hline Occupational category 5 & \multicolumn{2}{|c|}{11.5} & \multicolumn{2}{|c|}{8.5} \\
\hline Occupational category 6 & \multicolumn{2}{|c|}{4.6} & \multicolumn{2}{|c|}{2.9} \\
\hline Occupational category 7 & \multicolumn{2}{|c|}{0.6} & \multicolumn{2}{|c|}{1.3} \\
\hline Occupational category 8 & \multicolumn{2}{|c|}{2.7} & \multicolumn{2}{|c|}{1.8} \\
\hline Occupational category 9 & \multicolumn{2}{|c|}{3.7} & \multicolumn{2}{|c|}{1.6} \\
\hline Occupational category 10 & \multicolumn{2}{|c|}{2.2} & \multicolumn{2}{|c|}{1.1} \\
\hline Occupational category 11 & \multicolumn{2}{|c|}{1.9} & \multicolumn{2}{|c|}{1.2} \\
\hline Occupational category 12 & & & & 7 \\
\hline Occupational category 13 & & & & \\
\hline Occupational category 14 & & & & \\
\hline Occupational category 15 & & & & \\
\hline Occupational category 16 & & & & 5 \\
\hline Occupational category 17 & & & & \\
\hline Occupational category 18 & & & & .3 \\
\hline Occupational category 19 & & & & \\
\hline Occupational category 20 & & & & .3 \\
\hline
\end{tabular}

Table 5: Classification of the tasks

\begin{tabular}{||l|l||}
\hline Category & Tasks \\
\hline \hline Non-routine analytic & $\begin{array}{l}\text { developing, researching, designing and gathering information, investigat- } \\
\text { ing, documenting }\end{array}$ \\
\hline Non-routine interactive & $\begin{array}{l}\text { informing, advising and training, teaching, tutoring, educating and orga- } \\
\text { nizing, planning/preparing working processes and promoting, marketing, } \\
\text { public relations and buying, providing, selling and to be supervisor }\end{array}$ \\
\hline Routine cognitive & measuring, controlling, quality checks \\
\hline Routine manual & fabricating, producing goods and supervising, controlling machines and \\
& transporting, stocking, posting \\
\hline Non-routine manual & repairing, patching and nursing, serving, healing \\
\hline
\end{tabular}


Table 6: SO-Task-Index (averages) by skill-group for the years 1999 and 2006

\begin{tabular}{|c|c|c|c|c|c|c|c|c|}
\hline \multicolumn{9}{|l|}{ Category } \\
\hline & \multicolumn{2}{|c|}{ Low skilled } & \multicolumn{2}{|c|}{ Med skilled } & \multicolumn{2}{|c|}{ High skilled } & \multicolumn{2}{|c|}{ OVERALL } \\
\hline & 99 & 06 & 99 & 06 & 99 & 06 & 99 & 06 \\
\hline $\begin{array}{l}\text { Non-routine ana- } \\
\text { lytic }\end{array}$ & 8.3 & 23.6 & 15.7 & 26.2 & 43.8 & 54.4 & 20.1 & 32.3 \\
\hline $\begin{array}{l}\text { Non-routine in- } \\
\text { teractive }\end{array}$ & 16.6 & 21.5 & 30.2 & 28.6 & 46.5 & 41.5 & 32 & 31.0 \\
\hline $\begin{array}{l}\text { Routine cogni- } \\
\text { tive }\end{array}$ & 35.5 & 52.5 & 48.8 & 57.4 & 37.6 & 44.4 & 45.6 & 54.4 \\
\hline Routine manual & 43.7 & 40.9 & 39.8 & 35.5 & 17.8 & 12.8 & 36.2 & 30.8 \\
\hline $\begin{array}{l}\text { Non-routine } \\
\text { manual }\end{array}$ & 20.1 & 20 & 31.9 & 24.3 & 21.9 & 11.8 & 29.1 & 21.2 \\
\hline \multicolumn{9}{|c|}{ TOTAL CHANGE (06 - 99) } \\
\hline $\begin{array}{l}\text { Non-routine ana- } \\
\text { lytic }\end{array}$ & \multicolumn{2}{|c|}{15.3} & \multicolumn{2}{|c|}{10.5} & \multicolumn{2}{|c|}{10.6} & \multicolumn{2}{|c|}{12.2} \\
\hline $\begin{array}{l}\text { Non-routine in- } \\
\text { teractive }\end{array}$ & \multicolumn{2}{|c|}{4.9} & \multicolumn{2}{|c|}{-1.6} & \multicolumn{2}{|c|}{-5} & \multicolumn{2}{|c|}{-1} \\
\hline $\begin{array}{l}\text { Routine cogni- } \\
\text { tive }\end{array}$ & \multicolumn{2}{|c|}{17} & \multicolumn{2}{|c|}{8.6} & \multicolumn{2}{|c|}{6.8} & \multicolumn{2}{|c|}{8.8} \\
\hline Routine manual & \multicolumn{2}{|c|}{-2.8} & \multicolumn{2}{|c|}{-4.3} & \multicolumn{2}{|c|}{-5} & \multicolumn{2}{|c|}{-5.4} \\
\hline $\begin{array}{l}\text { Non-routine } \\
\text { manual }\end{array}$ & \multicolumn{2}{|c|}{-0.1} & \multicolumn{2}{|c|}{-7.6} & \multicolumn{2}{|c|}{-10.1} & \multicolumn{2}{|c|}{-7.9} \\
\hline
\end{tabular}


Table 7: AFL-Task-Index (averages) by skill-group for the years 1999 and 2006

\begin{tabular}{|c|c|c|c|c|c|c|c|c|}
\hline \multicolumn{9}{|l|}{ Category } \\
\hline & \multicolumn{2}{|c|}{ Low skilled } & \multicolumn{2}{|c|}{ Med skilled } & \multicolumn{2}{|c|}{ High skilled } & \multicolumn{2}{|c|}{ OVERALL } \\
\hline & 99 & 06 & 99 & 06 & 99 & 06 & 99 & 06 \\
\hline $\begin{array}{l}\text { Non-routine ana- } \\
\text { lytic }\end{array}$ & 3.2 & 10.9 & 6.1 & 11.7 & 17.9 & 26.8 & 8.0 & 14.9 \\
\hline $\begin{array}{l}\text { Non-routine in- } \\
\text { teractive }\end{array}$ & 23.4 & 28.3 & 36.1 & 36.1 & 56.4 & 52.7 & 38.7 & 39.4 \\
\hline $\begin{array}{l}\text { Routine cogni- } \\
\text { tive }\end{array}$ & 8.9 & 14.8 & 10.7 & 13.4 & 6.8 & 8.8 & 9.8 & 12.4 \\
\hline Routine manual & 52.5 & 36.9 & 31.7 & 27.0 & 10.1 & 7.6 & 29.7 & 23.3 \\
\hline $\begin{array}{l}\text { Non-routine } \\
\text { manual }\end{array}$ & 11.7 & 9.1 & 15.2 & 11.7 & 8.7 & 4.1 & 13.8 & 9.9 \\
\hline \multicolumn{9}{|c|}{ TOTAL CHANGE (06 - 99) } \\
\hline $\begin{array}{l}\text { Non-routine ana- } \\
\text { lytic }\end{array}$ & \multicolumn{2}{|c|}{7.7} & \multicolumn{2}{|c|}{5.6} & \multicolumn{2}{|c|}{8.9} & \multicolumn{2}{|c|}{6.9} \\
\hline $\begin{array}{l}\text { Non-routine in- } \\
\text { teractive }\end{array}$ & \multicolumn{2}{|c|}{4.9} & \multicolumn{2}{|c|}{0} & \multicolumn{2}{|c|}{-3.7} & \multicolumn{2}{|c|}{0.7} \\
\hline $\begin{array}{l}\text { Routine cogni- } \\
\text { tive }\end{array}$ & \multicolumn{2}{|c|}{5.9} & \multicolumn{2}{|c|}{2.7} & \multicolumn{2}{|c|}{2} & \multicolumn{2}{|c|}{2.6} \\
\hline Routine manual & \multicolumn{2}{|c|}{-15.6} & \multicolumn{2}{|c|}{-4.7} & \multicolumn{2}{|c|}{-2.5} & \multicolumn{2}{|c|}{-6.4} \\
\hline $\begin{array}{l}\text { Non-routine } \\
\text { manual }\end{array}$ & \multicolumn{2}{|c|}{-2.6} & \multicolumn{2}{|c|}{-3.5} & \multicolumn{2}{|c|}{-4.6} & \multicolumn{2}{|c|}{-3.9} \\
\hline
\end{tabular}

Table 8: Subjective Job Complexity SJC (averages) by skill groups for the years 1999 and 2006

\begin{tabular}{|c|c|c|c|c|c|c|c|c|}
\hline & \multicolumn{2}{|c|}{ Low skilled } & \multicolumn{2}{|c|}{ Med skilled } & \multicolumn{2}{|c|}{ High skilled } & \multicolumn{2}{|c|}{ OVERALL } \\
\hline & 99 & 06 & 99 & 06 & 99 & 06 & 99 & 06 \\
\hline $\begin{array}{l}\text { Subjective Job Com- } \\
\text { plexity }\end{array}$ & 2.8 & 3.1 & 3.4 & 3.6 & 4.6 & 4.7 & 3.5 & 3.8 \\
\hline \multicolumn{9}{|c|}{ TOTAL CHANGE (06 - 99) } \\
\hline $\begin{array}{l}\text { Subjecitve Job Com- } \\
\text { plexity }\end{array}$ & & & & 2 & & 1 & & .3 \\
\hline
\end{tabular}


Table 9: Objective Job Complexity NJC (averages) by skill groups for the years 1999 and 2006

\begin{tabular}{||l|l|l|l|l|l|l||l|l||}
\hline & \multicolumn{1}{|c|}{ Low skilled } & \multicolumn{2}{c||}{ Med skilled } & \multicolumn{2}{c||}{ High skilled } & \multicolumn{2}{c||}{ OVERALL } \\
\hline & $\mathbf{9 9}$ & $\mathbf{0 6}$ & $\mathbf{9 9}$ & $\mathbf{0 6}$ & $\mathbf{9 9}$ & $\mathbf{0 6}$ & $\mathbf{9 9}$ & $\mathbf{0 6}$ \\
\hline $\begin{array}{l}\text { Objective Job Com- } \\
\text { plexity }\end{array}$ & 3.14 & 4.02 & 4.37 & 4.49 & 4.98 & 4.61 & 4.39 & 4.5 \\
\hline \multicolumn{8}{|c||}{ TOTAL CHANGE (06 - 99) } \\
\hline $\begin{array}{l}\text { Objective Job Com- } \\
\text { plexity }\end{array}$ & \multicolumn{3}{|c||}{0.12} & \multicolumn{3}{|c||}{-0.37} & 0.11 \\
\hline
\end{tabular}

Table 10: Estimated Model 1999: AFLTask-Index without occupations

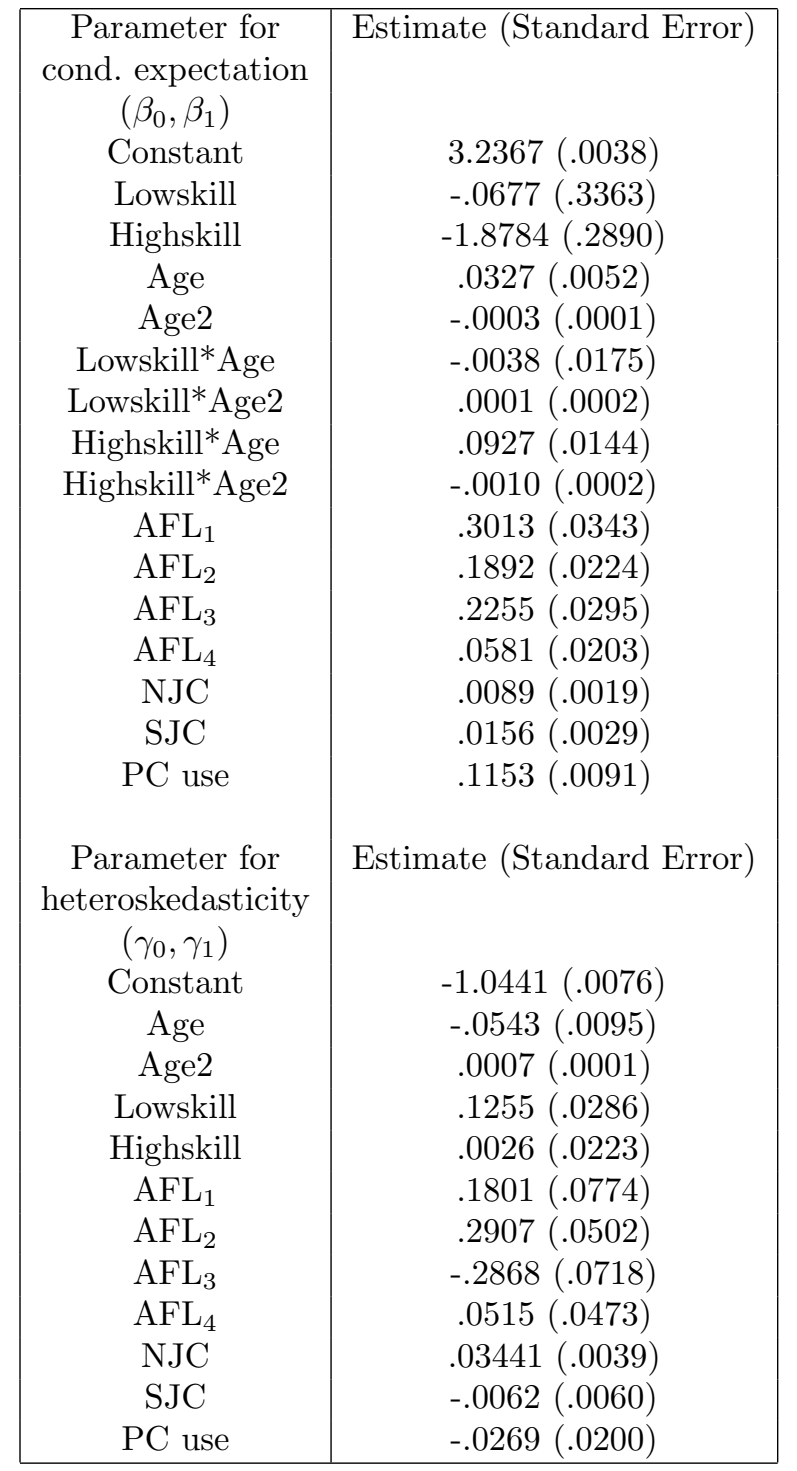

Table 11: Estimated Model 2006: AFLTask-Index without occupations

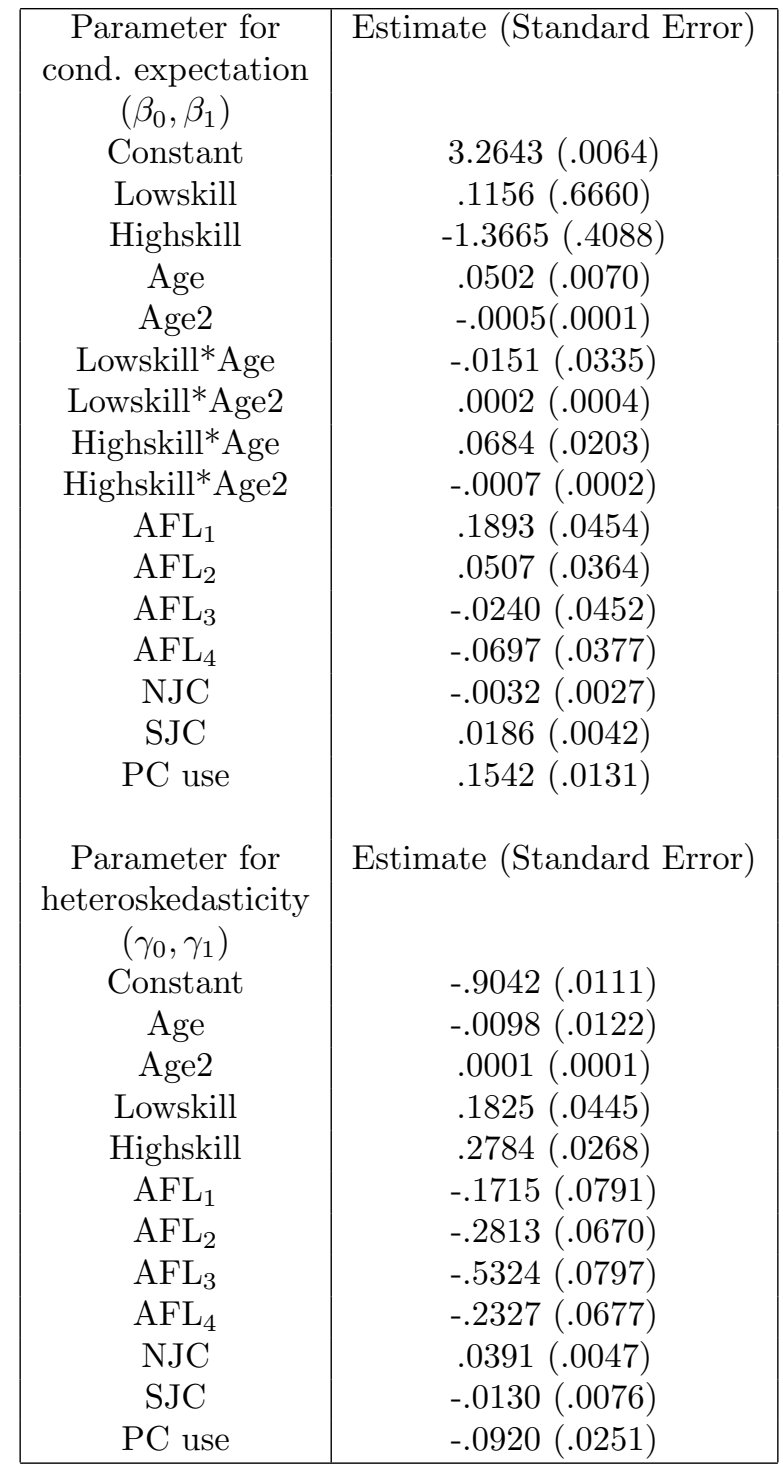


Table 12: Estimated Model 1999: AFLTask-Index with occupations

\begin{tabular}{|c|c|}
\hline $\begin{array}{c}\text { Parameter for } \\
\text { cond. expectation } \\
\left(\beta_{0}, \beta_{1}\right)\end{array}$ & Estimate (Standard Error) \\
\hline Constant & $3.2363(.0037)$ \\
\hline Lowskill & $.0946(.3269)$ \\
\hline Highskill & $-1.6854(.2810)$ \\
\hline Age & $.0335(.0050)$ \\
\hline Age2 & $-.0003(.0001)$ \\
\hline Lowskill*Age & $-.0117(.0169)$ \\
\hline Lowskill*Age2 & $.0002(.0002)$ \\
\hline Highskill*Age & $.0820(.0140)$ \\
\hline Highskill*Age2 & $-.0009(.0002)$ \\
\hline Occup1 & $-.3808(.0323)$ \\
\hline Occup2 & $.0301(.0285)$ \\
\hline Occup3 & $.0685(.0354)$ \\
\hline Occup4 & $.0246(.0280)$ \\
\hline Occup5 & $.0321(.0196)$ \\
\hline Occup6 & $-.0056(.0231)$ \\
\hline Occup7 & $.0212(.0468)$ \\
\hline Occup8 & $-.1344(.0290)$ \\
\hline Occup9 & $-.0249(.0241)$ \\
\hline Occup10 & $-.0358(.0285)$ \\
\hline Occup11 & $-.0639(.0286)$ \\
\hline Occup12 & $.0079(.0344)$ \\
\hline Occup14 & $.1036(.0216)$ \\
\hline Occup15 & $-.1495(.0265)$ \\
\hline Occup16 & $.0608(.0276)$ \\
\hline Occup17 & $-.0889(.0201)$ \\
\hline Occup18 & $.0549(.0219)$ \\
\hline Occup19 & $-.0268(.0240)$ \\
\hline Occup20 & $-.0331(.0221)$ \\
\hline $\mathrm{AFL}_{1}$ & $.2694(.0346)$ \\
\hline $\mathrm{AFL}_{2}$ & $.2145(.0234)$ \\
\hline $\mathrm{AFL}_{3}$ & $.1775(.0297)$ \\
\hline $\mathrm{AFL}_{4}$ & $.0869(.0217)$ \\
\hline NJC & $.0097(.0019)$ \\
\hline SJC & $.0113(.0028)$ \\
\hline PC use & $.0791(.0096)$ \\
\hline Parameter for & Estimate (Standard Error) \\
\hline $\begin{array}{l}\text { heteroskedasticity } \\
\qquad\left(\gamma_{0}, \gamma_{1}\right)\end{array}$ & \\
\hline Constant & $-1.0696(.0076)$ \\
\hline Age & $-.0449(.0095)$ \\
\hline Age2 & $.0006(.0001)$ \\
\hline Lowskill & $.1263(.0288)$ \\
\hline Highskill & $.0049(.0224)$ \\
\hline $\mathrm{AFL}_{1}$ & $.1376(.0786)$ \\
\hline $\mathrm{AFL}_{2}$ & $.3413(.0504)$ \\
\hline $\mathrm{AFL}_{3}$ & $-.2772(.0726)$ \\
\hline $\mathrm{AFL}_{4}$ & $.0604(.0477)$ \\
\hline NJC & $.0294(.0039)$ \\
\hline SJC & $-.0063(.0061)$ \\
\hline PC use & $-.0250(.0200)$ \\
\hline
\end{tabular}

Table 13: Estimated Model 2006: AFLTask-Index with occupations

\begin{tabular}{|c|c|}
\hline $\begin{array}{l}\text { Parameter for } \\
\text { cond. expectation } \\
\qquad\left(\beta_{0}, \beta_{1}\right)\end{array}$ & Estimate (Standard Error) \\
\hline Constant & $3.271(.0065)$ \\
\hline Lowskill & $.0622(.6611)$ \\
\hline Highskill & $-1.2227(.4028)$ \\
\hline Age & $.0509(.0068)$ \\
\hline Age2 & $-.0005(.0001)$ \\
\hline Lowskill*Age & $-.0124(.0332)$ \\
\hline Lowskill*Age2 & $.0002(.0004)$ \\
\hline Highskill*Age & $.0602(.0199)$ \\
\hline Highskill*Age2 & $-.0006(.0002)$ \\
\hline Occup1 & $-.1737(.0385)$ \\
\hline Occup2 & $.0163(.0405)$ \\
\hline Occup3 & $.1129(.0526)$ \\
\hline Occup4 & $.1409(.0332)$ \\
\hline Occup5 & $.0544(.0273)$ \\
\hline Occup6 & $.0134(.0334)$ \\
\hline Occup7 & $.1023(.0514)$ \\
\hline Occup8 & $-.1801(.0437)$ \\
\hline Occup9 & $-.0500(.0412)$ \\
\hline Occup10 & $-.0977(.0456)$ \\
\hline Occup11 & $-.1093(.0428)$ \\
\hline Occup12 & $-.0171(.0549)$ \\
\hline Occup14 & $.1277(.0288)$ \\
\hline Occup15 & $-.0977(.0349)$ \\
\hline Occup16 & $.1539(.0354)$ \\
\hline Occup17 & $-.2020(.0277)$ \\
\hline Occup18 & $.0465(.0284)$ \\
\hline Occup19 & $-.1173(.0341)$ \\
\hline Occup20 & $-.0599(.0308)$ \\
\hline $\mathrm{AFL}_{1}$ & $.1711(.0475)$ \\
\hline $\mathrm{AFL}_{2}$ & $.1108(.0391)$ \\
\hline $\mathrm{AFL}_{3}$ & $-.0877(.0451)$ \\
\hline $\mathrm{AFL}_{4}$ & $.0103(.0400)$ \\
\hline NJC & $-.0027(.0027)$ \\
\hline SJC & $.0129(.0042)$ \\
\hline PC use & $.1042(.0137)$ \\
\hline Parameter for & Estimate (Standard Error) \\
\hline $\begin{array}{l}\text { heteroskedasticity } \\
\qquad\left(\gamma_{0}, \gamma_{1}\right)\end{array}$ & \\
\hline Constant & $-.9343(.0112)$ \\
\hline Age & $-.0151(.0124)$ \\
\hline Age2 & $.0002(.0002)$ \\
\hline Lowskill & $.2117(.0448)$ \\
\hline Highskill & $.2856(.0266)$ \\
\hline $\mathrm{AFL}_{1}$ & $-.2430(.0794)$ \\
\hline $\mathrm{AFL}_{2}$ & $-.3202(.0672)$ \\
\hline $\mathrm{AFL}_{3}$ & $-.6392(.0796)$ \\
\hline $\mathrm{AFL}_{4}$ & $-.2919(.0673)$ \\
\hline NJC & $.0367(.0047)$ \\
\hline SJC & $-.0081(.0077)$ \\
\hline PC use & $-.0774(.0254)$ \\
\hline
\end{tabular}


Table 14: Estimated Model 1999: SOTask-Index without occupations

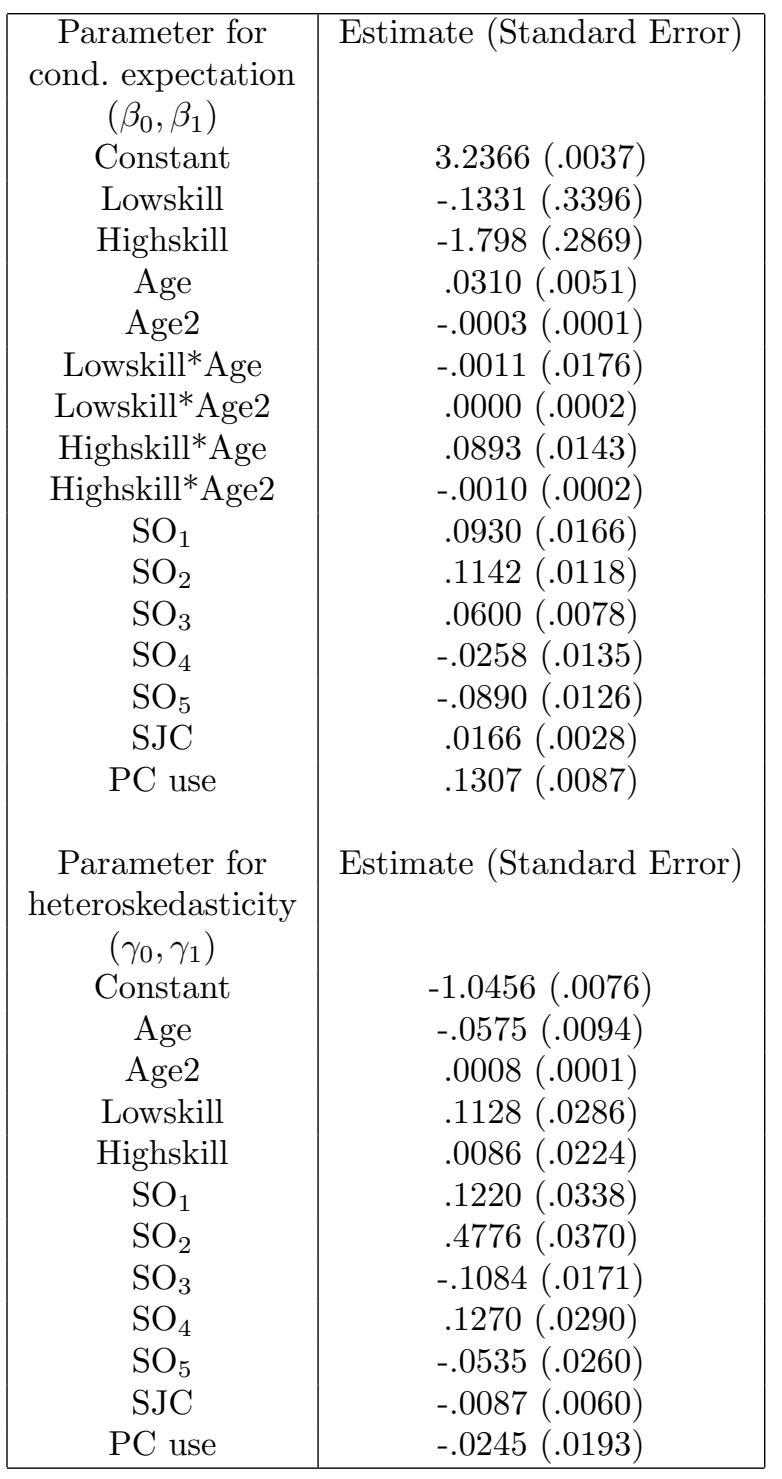

Table 15: Estimated Model 2006: SOTask-Index without occupations

\begin{tabular}{|c|c|}
\hline $\begin{array}{c}\text { Parameter for } \\
\text { cond. expectation } \\
\left(\beta_{0}, \beta_{1}\right)\end{array}$ & Estimate (Standard Error) \\
\hline Constant & $3.2626(.0067)$ \\
\hline Lowskill & $.0938(.6684)$ \\
\hline Highskill & $-1.4924(.3976)$ \\
\hline Age & $.0452(.0070)$ \\
\hline Age2 & $-.0005(.0001)$ \\
\hline Lowskill*Age & $-.0145(.0335)$ \\
\hline Lowskill*Age2 & $.0002(.0004)$ \\
\hline Highskill*Age & $.0753(.0197)$ \\
\hline Highskill*Age2 & $-.0008(.0002)$ \\
\hline $\mathrm{SO}_{1}$ & $.0972(.0206)$ \\
\hline $\mathrm{SO}_{2}$ & $.0162(.0249)$ \\
\hline $\mathrm{SO}_{3}$ & $-.0070(.0117)$ \\
\hline $\mathrm{SO}_{4}$ & $-.0688(.0193)$ \\
\hline $\mathrm{SO}_{5}$ & $-.0639(.0215)$ \\
\hline SJC & $.0179(.0041)$ \\
\hline $\mathrm{PC}$ use & $.1584(.0127)$ \\
\hline Parameter for & Estimate (Standard Error) \\
\hline $\begin{array}{l}\text { heteroskedasticity } \\
\qquad\left(\gamma_{0}, \gamma_{1}\right)\end{array}$ & \\
\hline Constant & $-.9043(.0114)$ \\
\hline Age & $-.0077(.0123)$ \\
\hline Age2 & $.0000(.0002)$ \\
\hline Lowskill & $.1724(.0444)$ \\
\hline Highskill & $.2104(.0278)$ \\
\hline $\mathrm{SO}_{1}$ & $.2334(.0366)$ \\
\hline $\mathrm{SO}_{2}$ & $.2352(.0449)$ \\
\hline $\mathrm{SO}_{3}$ & $-.1446(.0215)$ \\
\hline $\mathrm{SO}_{4}$ & $.0987(.0363)$ \\
\hline $\mathrm{SO}_{5}$ & $.2256(.0368)$ \\
\hline SJC & $-.0229(.0077)$ \\
\hline PC use & $-.1189(.0247)$ \\
\hline
\end{tabular}


Table 16: Estimated Model 1999: SOTask-Index with occupations

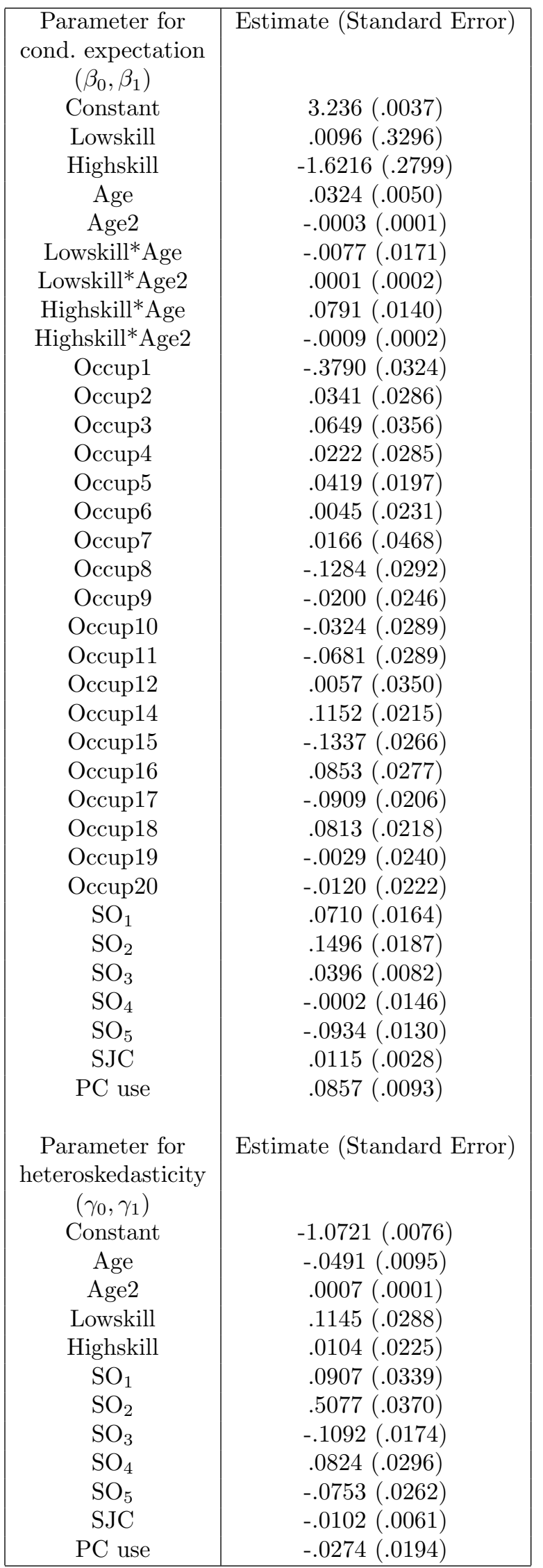

Table 17: Estimated Model 2006: SOTask-Index with occupations

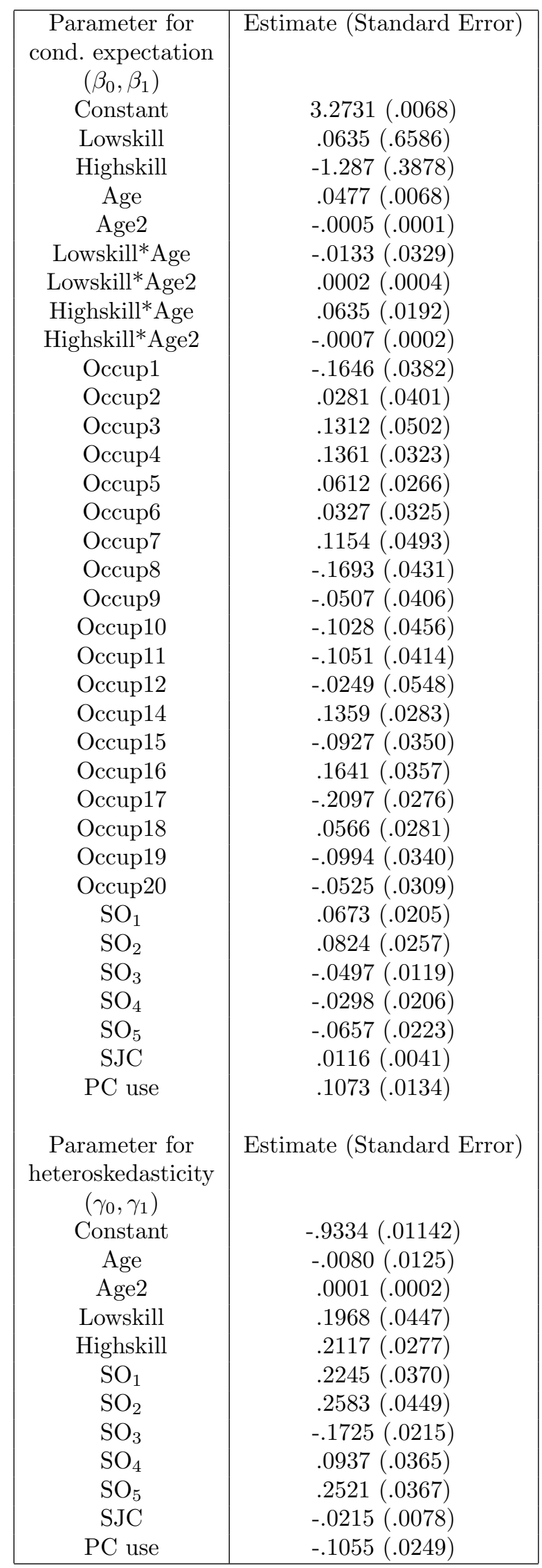


Table 18: Decomposition of 80-20 Wage Differential - AFL-Task-Index without occupations (based on estimates in Tables 10 and 11)

\begin{tabular}{c|ccc} 
& $80-20$ & $80-50$ & $50-20$ \\
\hline Overall: 06-99 & $0.077(0.011)$ & $0.032(0.007)$ & $0.045(0.007)$ \\
\hline Char. P & $0.03(0.007)$ & $0.016(0.005)$ & $0.014(0.005)$ \\
\hline Char. T & $-0.041(0.005)$ & $-0.018(0.003)$ & $-0.023(0.004)$ \\
\hline Coef. P & $0.008(0.005)$ & $0.011(0.004)$ & $-0.003(0.003)$ \\
\hline Coef. T & $0.0004(0.006)$ & $-0.015(0.004)$ & $0.016(0.004)$ \\
\hline & & & \\
Unexplained & $0.079(0.008)$ & $0.038(0.004)$ & $0.041(0.004)$ \\
\hline
\end{tabular}

Table 19: Decomposition of 80-20 Wage Differential - AFL-Task-Index with occupations (based on estimates in Tables 12 and 13)

\begin{tabular}{c|ccc} 
& $80-20$ & $80-50$ & $50-20$ \\
\hline Overall: 06-99 & $0.085(0.011)$ & $0.039(0.007)$ & $0.046(0.007)$ \\
\hline Char. P & $0.024(0.007)$ & $0.015(0.005)$ & $0.009(0.005)$ \\
\hline Char. T & $-0.026(0.004)$ & $-0.012(0.003)$ & $-0.013(0.003)$ \\
\hline Coef. P & $0.02(0.007)$ & $0.015(0.004)$ & $0.005(0.004)$ \\
\hline Coef. T & $-0.003(0.007)$ & $-0.013(0.005)$ & $0.01(0.004)$ \\
\hline & & & \\
Unexplained & $0.07(0.008)$ & $0.034(0.004)$ & $0.036(0.004)$ \\
\hline
\end{tabular}


Table 20: Decomposition of 80-20 Wage Differential - SO-Task-Index without occupations (based on estimates in Tables 14 and 15)

\begin{tabular}{c|ccc} 
& $80-20$ & $80-50$ & $50-20$ \\
\hline Overall: 06-99 & $0.077(0.011)$ & $0.035(0.007)$ & $0.042(0.007)$ \\
\hline Char. P & $0.02(0.007)$ & $0.013(0.005)$ & $0.008(0.005)$ \\
\hline Char. T & $-0.033(0.005)$ & $-0.014(0.004)$ & $-0.019(0.004)$ \\
\hline Coef. P & $0.008(0.005)$ & $0.01(0.004)$ & $-0.002(0.003)$ \\
\hline Coef. T & $0.004(0.006)$ & $-0.01(0.004)$ & $0.014(0.004)$ \\
\hline & & & \\
Unexplained & $0.079(0.009)$ & $0.037(0.004)$ & $0.042(0.004)$ \\
\hline
\end{tabular}

Table 21: Decomposition of 80-20 Wage Differential - SO-Task-Index with occupations (based on estimates in Tables 16 and 17)

\begin{tabular}{c|ccc} 
& $80-20$ & $80-50$ & $50-20$ \\
\hline Overall: 06-99 & $0.083(0.011)$ & $0.039(0.007)$ & $0.044(0.006)$ \\
\hline Char. P & $0.015(0.007)$ & $0.013(0.005)$ & $0.002(0.005)$ \\
\hline Char. T & $-0.024(0.005)$ & $-0.013(0.003)$ & $-0.011(0.003)$ \\
\hline Coef. P & $0.019(0.008)$ & $0.011(0.005)$ & $0.008(0.004)$ \\
\hline Coef. T & $0.002(0.008)$ & $-0.009(0.005)$ & $0.011(0.004)$ \\
\hline & & & \\
Unexplained & $0.071(0.008)$ & $0.037(0.004)$ & $0.034(0.004)$ \\
\hline
\end{tabular}


Figure 1: Univariate density estimates of unconditional wages

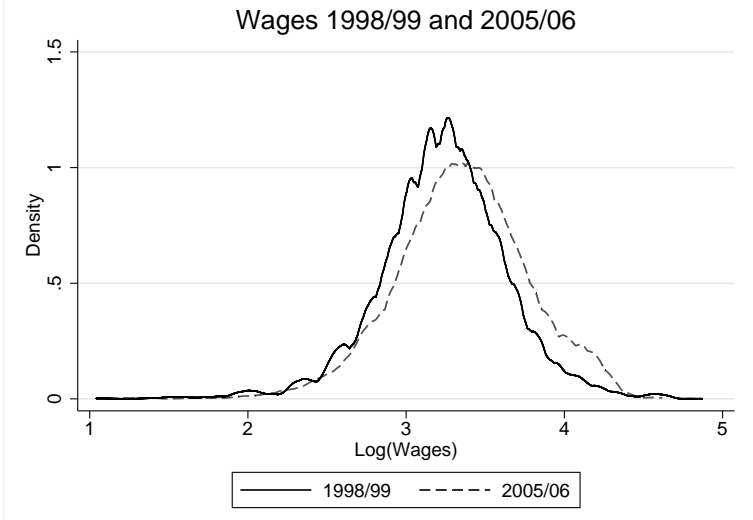


Figure 2: Decomposition of Changes in Wage Distribution - AFL-Task-Index without occupations (based on estimates in Tables 10 and 11)

Overall

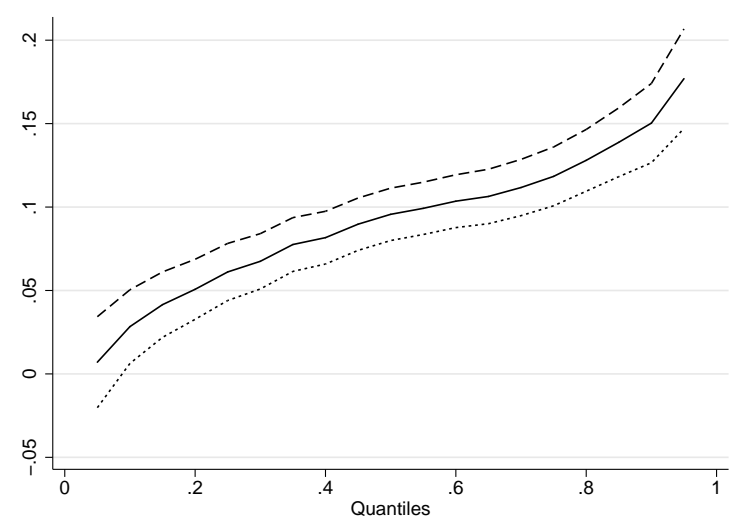

Task Characterstic Effect (Char. T)

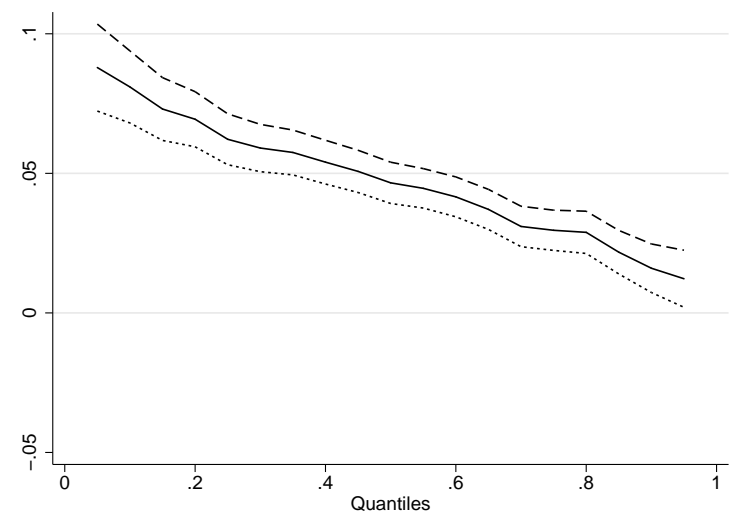

Personal Coefficient Effect (Coef. P)

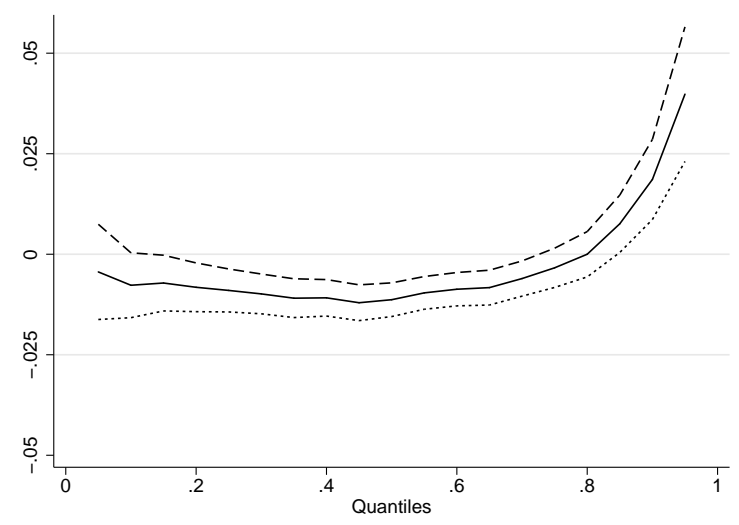

Personal Characteristic Effect (Char. P)

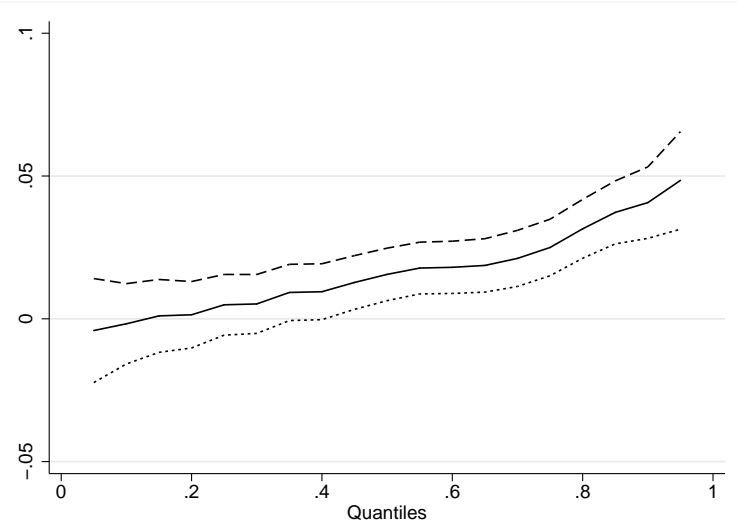

Unexplained

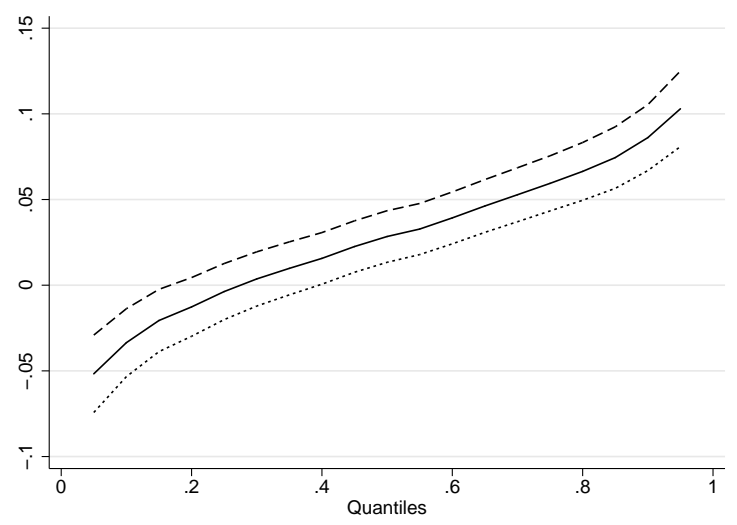

Task Coefficient Effect (Coef. T)

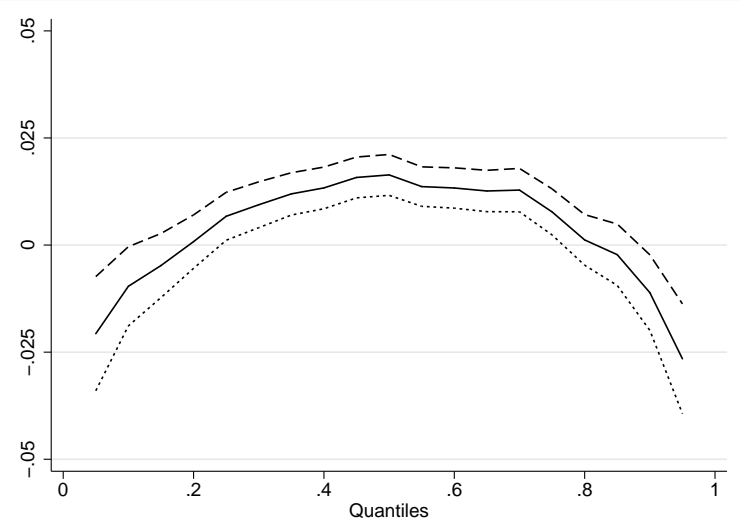


Figure 3: Decomposition of Changes in Wage Distribution - AFL-Task-Index with occupations (based on estimates in Tables 12 and 13)

Overall

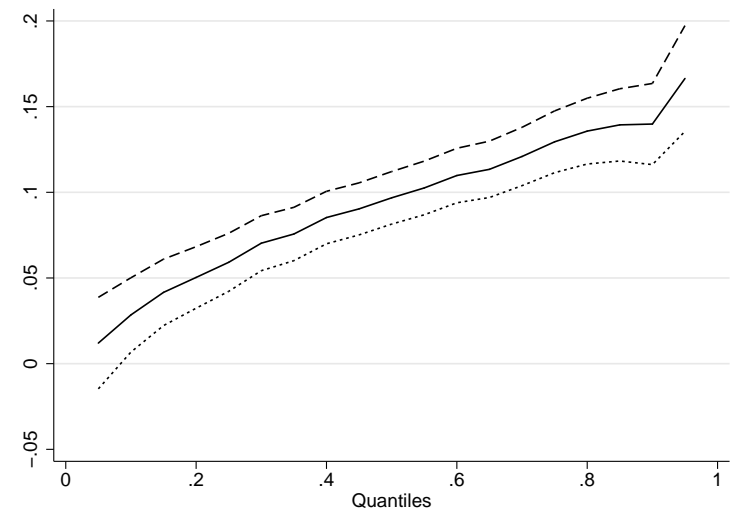

Task Charactersitc Effect (Char. T)

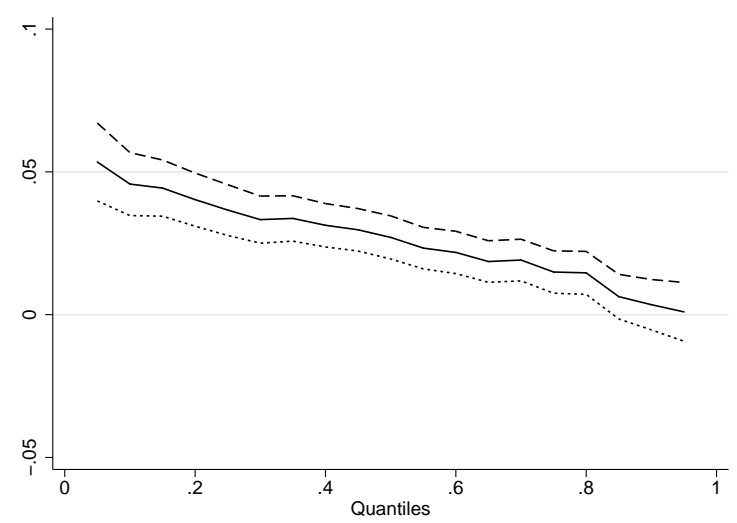

Personal Coefficient Effect (Coef. P)

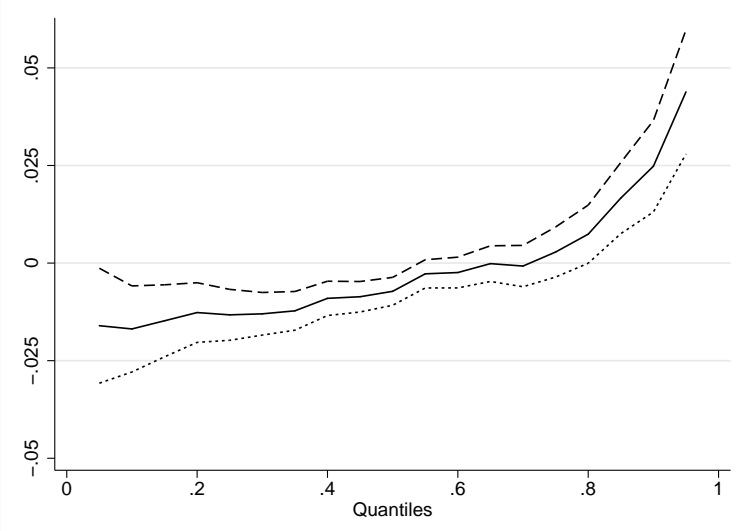

Personal Characteristic Effect (Char. P)

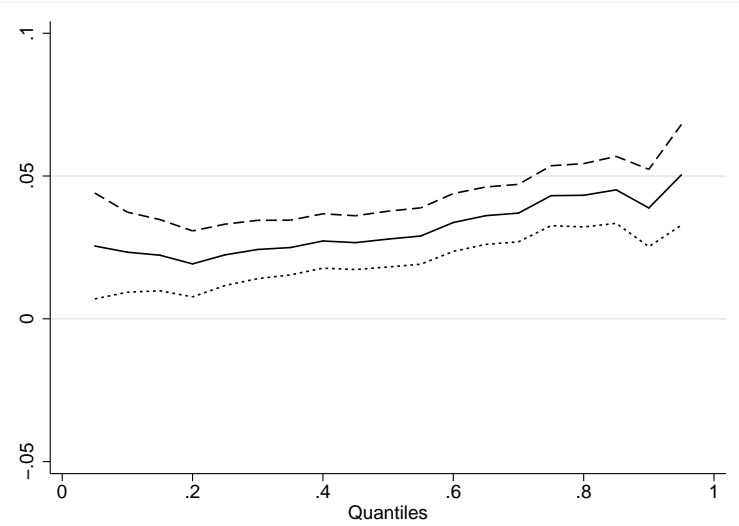

Unexplained

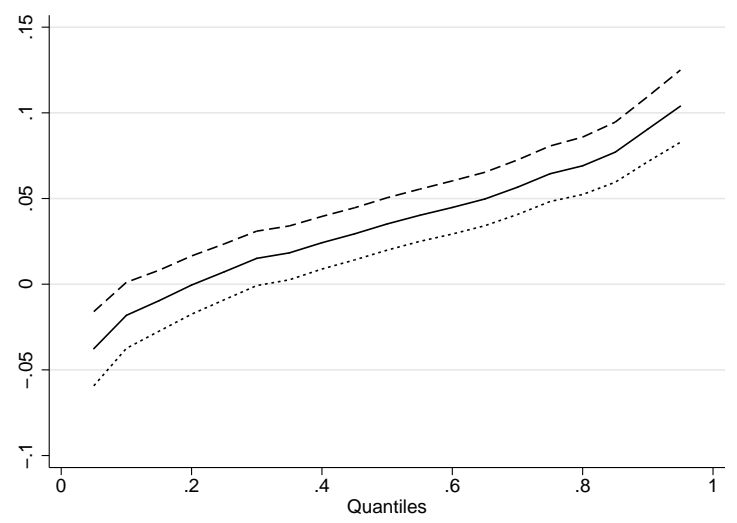

Task Coefficient Effect (Coef. T)

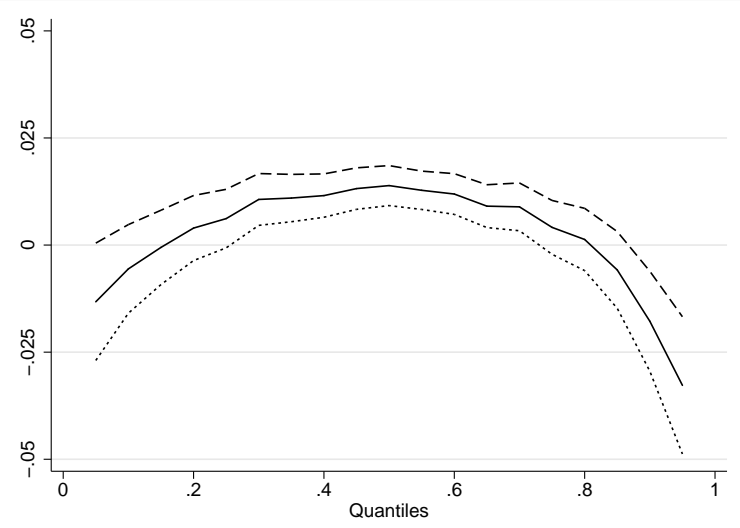


Figure 4: Decomposition of Changes in Wage Distribution - SO-Task-Index without occupations (based on estimates in Tables 14 and 15)

Overall

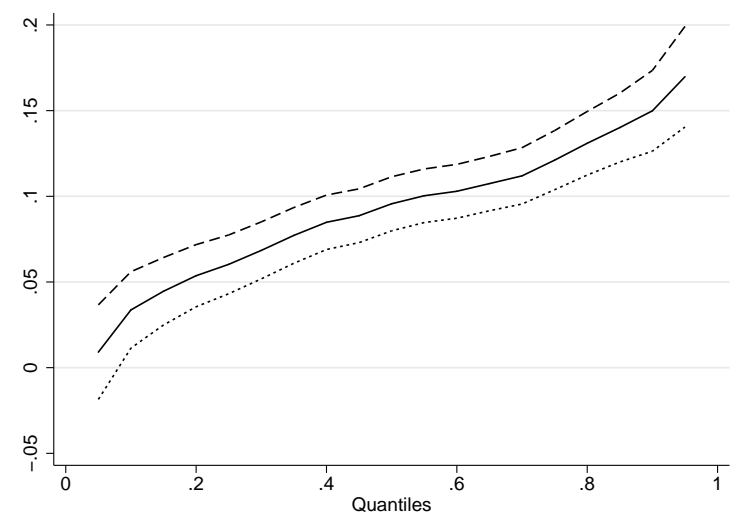

Task Charactersitc Effect (Char. T)

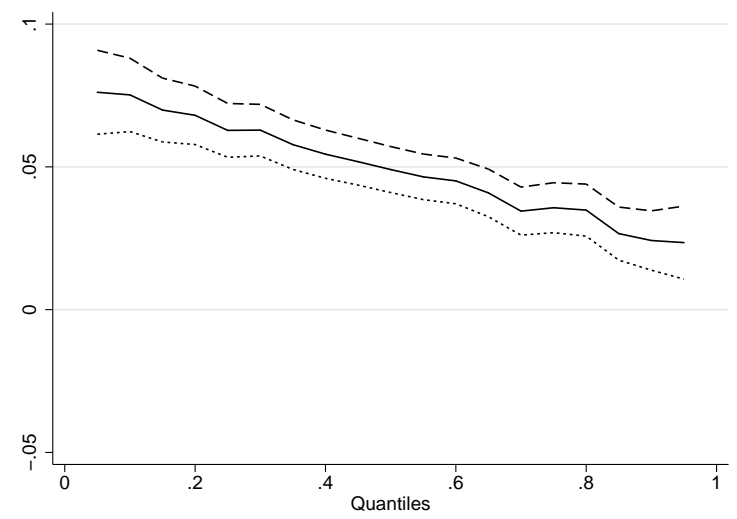

Personal Coefficient Effect (Coef. P)

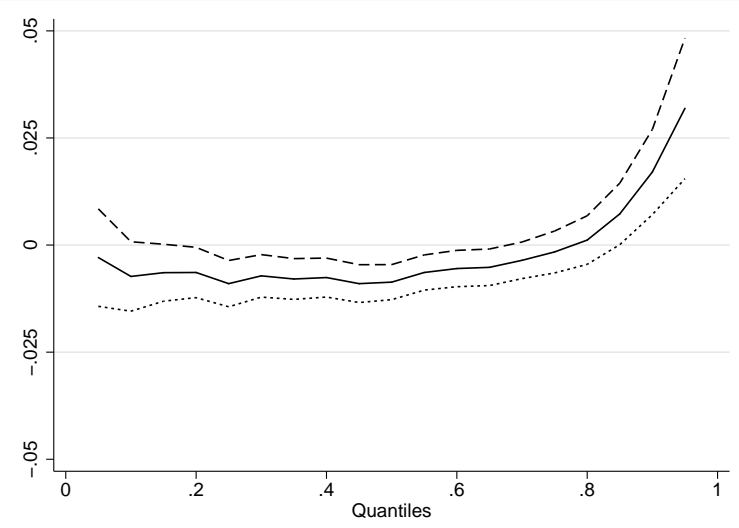

Personal Characteristic Effect (Char. P)

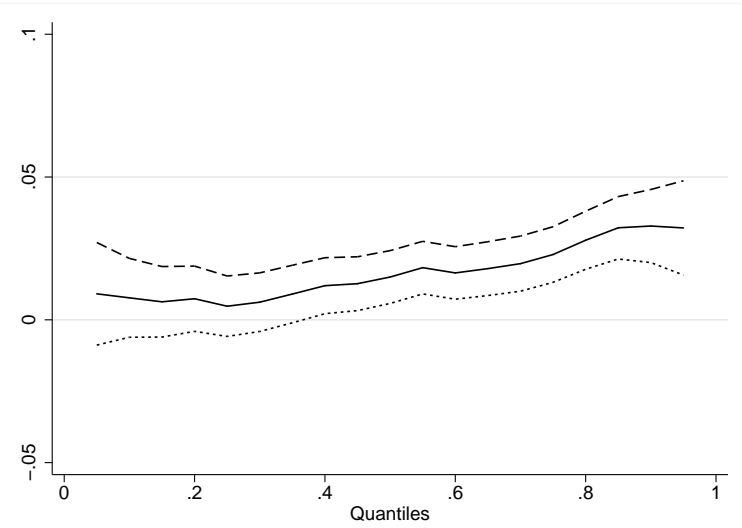

Unexplained

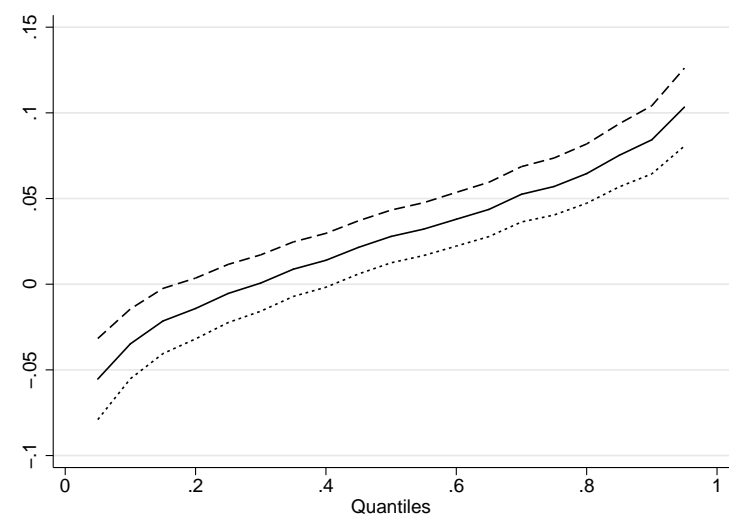

Task Coefficient Effect (Coef. T)

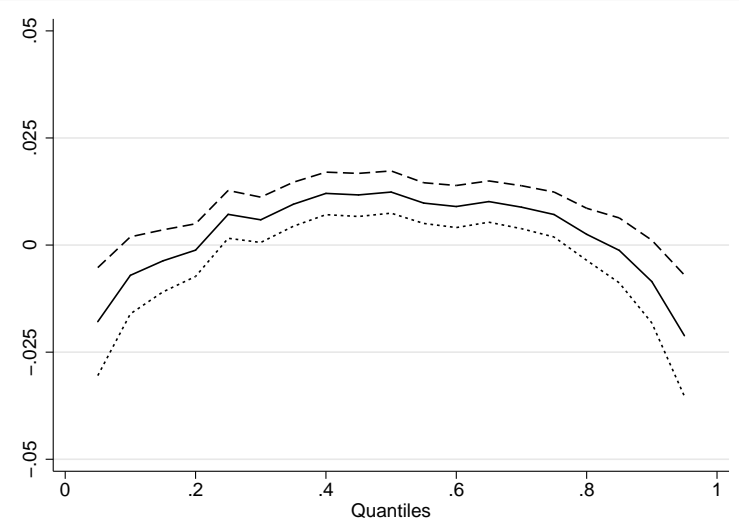


Figure 5: Decomposition of Changes in Wage Distribution - SO-Task-Index with occupations (based on estimates in Tables 16 and 17)

Overall

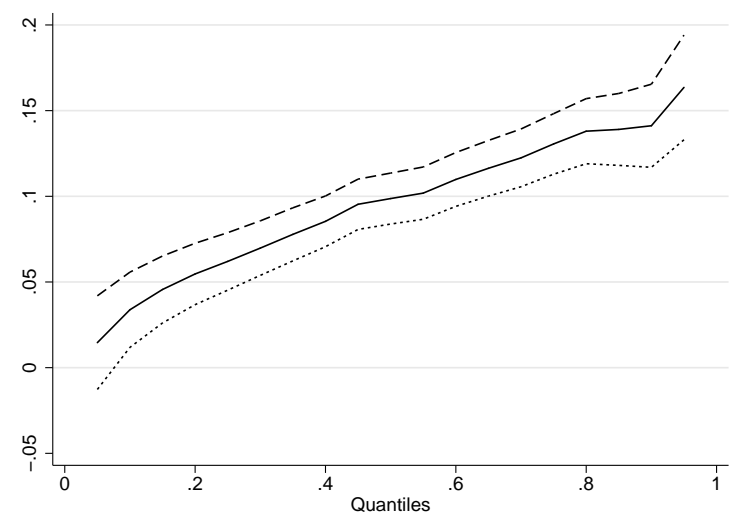

Task Charactersitc Effect (Char. T)

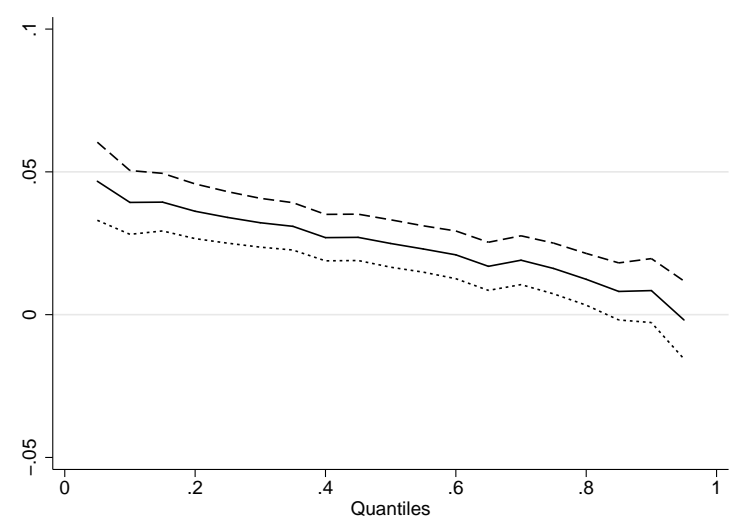

Personal Coefficient Effect (Coef. P)

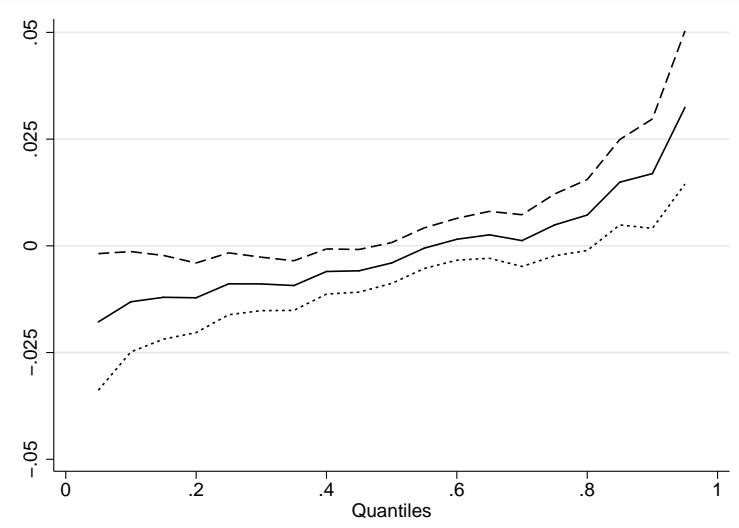

Personal Characteristic Effect (Char. P)

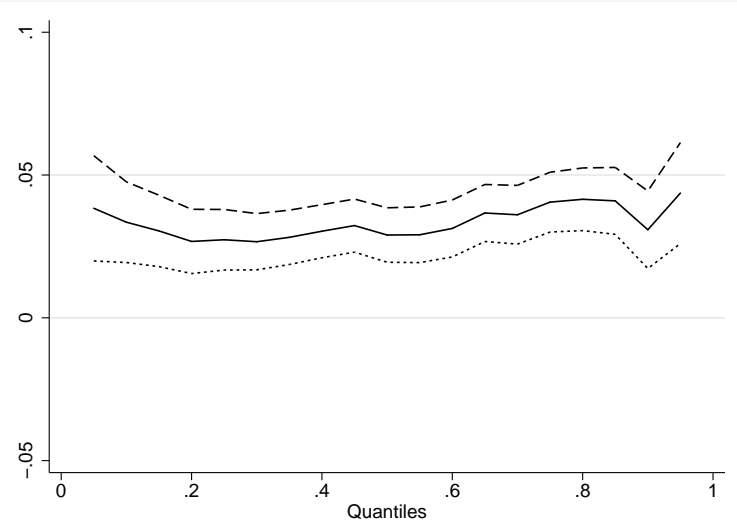

Unexplained

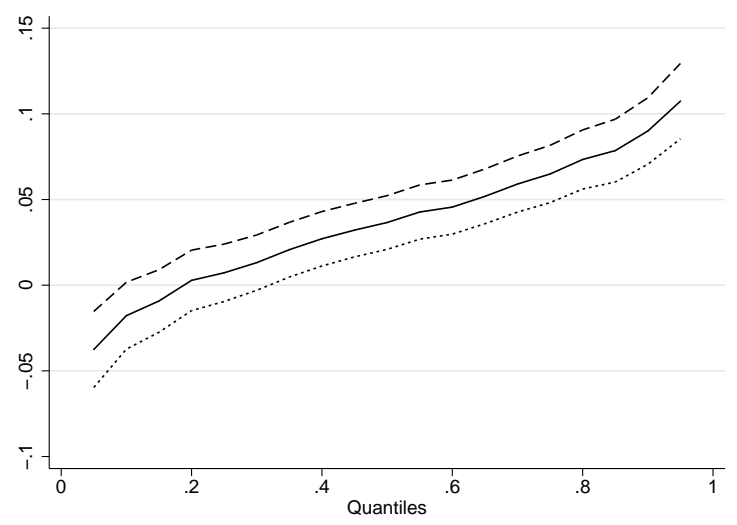

Task Coefficient Effect (Coef. T)

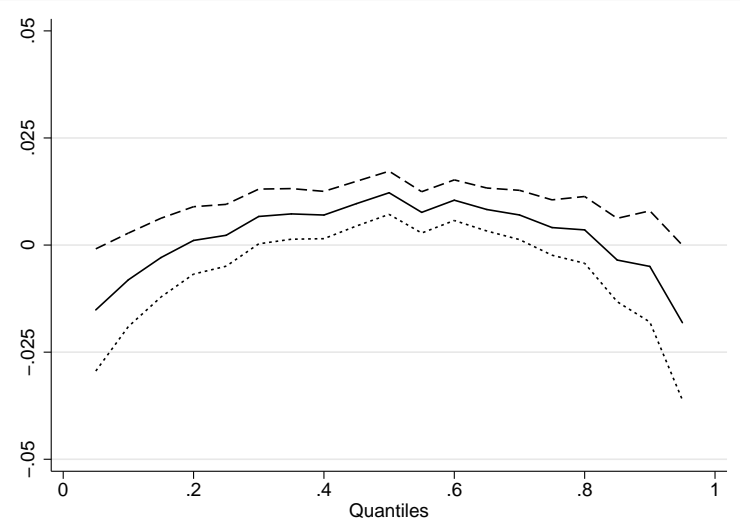

